\title{
Comparative Costs of Flexible Package Cells and Rigid Cells for Lithium-lon Hybrid Electric Vehicle Batteries
}

Chemical Engineering Division

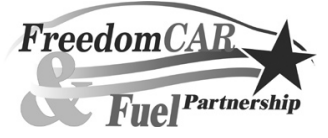




\begin{abstract}
About Argonne National Laboratory
Argonne is a U.S. Department of Energy laboratory managed by UChicago Argonne, LLC under contract DE-AC02-06CH11357. The Laboratory's main facility is outside Chicago, at 9700 South Cass Avenue, Argonne, Illinois 60439. For information about Argonne, see www.anl.gov.
\end{abstract}

\title{
Availability of This Report
}

This report is available, at no cost, at http://www.osti.gov/bridge. It is also available on paper to the U.S. Department of Energy and its contractors, for a processing fee, from:

U.S. Department of Energy

Office of Scientific and Technical Information

P.O. Box 62

Oak Ridge, TN 37831-0062

phone (865) 576-8401

fax (865) 576-5728

reports@adonis.osti.gov

\begin{abstract}
Disclaimer
This report was prepared as an account of work sponsored by an agency of the United States Government. Neither the United States Government nor any agency thereof, nor UChicago Argonne, LLC, nor any of their employees or officers, makes any warranty, express or implied, or assumes any legal liability or responsibility for the accuracy, completeness, or usefulness of any information, apparatus, product, or process disclosed, or represents that its use would not infringe privately owned rights. Reference herein to any specific commercial product, process, or service by trade name, trademark, manufacturer, or otherwise, does not necessarily constitute or imply its endorsement, recommendation, or favoring by the United States Government or any agency thereof. The views and opinions of document authors expressed herein do not necessarily state or reflect those of the United States Government or any agency thereof, Argonne National Laboratory, or UChicago Argonne, LLC.
\end{abstract}




\begin{abstract}
ANL-06/43
ARGONNE NATIONAL LABORATORY

9700 S. Cass Avenue

Argonne, IL 60439
\end{abstract}

\title{
Comparative Costs of Flexible Package Cells and Rigid Cells for Lithium-Ion Hybrid Electric Vehicle Batteries
}

\author{
by \\ Paul A. Nelson and Andrew N. Jansen
}

Chemical Engineering Division

June 2006 


\section{CONTENTS}

$\underline{\text { Page }}$

ACKNOWLEDGEMENTS ................................................................................. vi

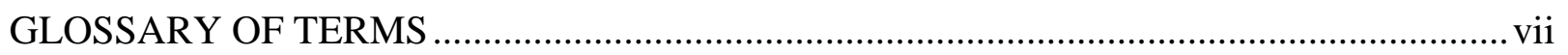

EXECUTIVE SUMMARY ..................................................................................... 1

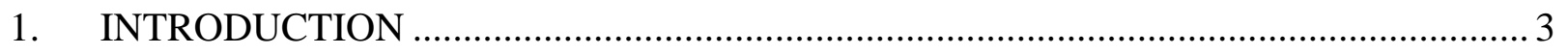

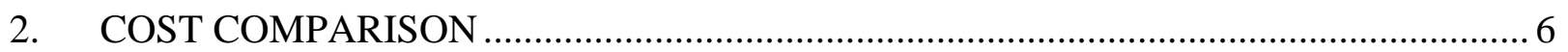

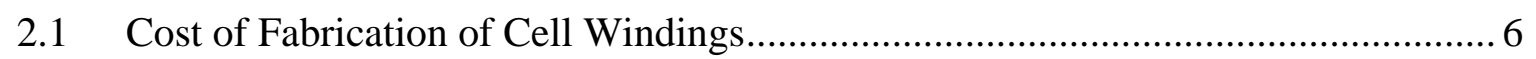

2.2 Cost of Attachment of Electrodes to Terminals ................................................ 8

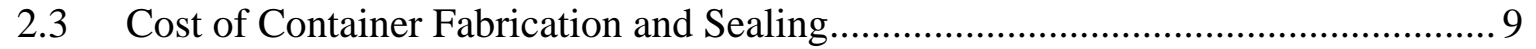

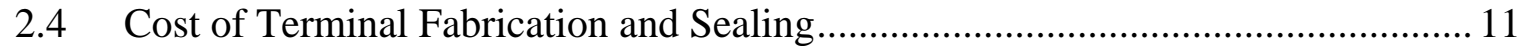

2.5 Cost of Provision for Cooling Channels............................................................. 12

2.6 Cost of Pressure Relief and Pressure Sensing ................................................. 13

2.7 Cost of Intercell Connections ....................................................................... 13

2.8 Cost of Module and Battery Hardware.......................................................... 15

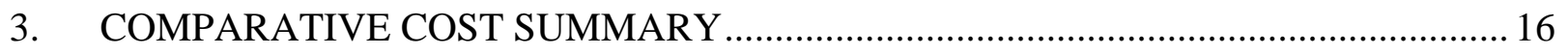

4. RIGID CONTAINER WITH POLYMER-SEALED TERMINALS ........................... 17

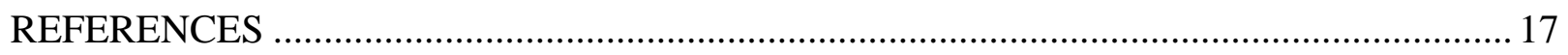

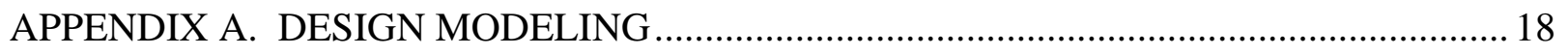

APPENDIX B. THERMAL MANAGEMENT ................................................................ 25

APPENDIX C. SAFETY AND MONITORING ........................................................... 30

APPENDIX D. COMPANY CONTACT INFORMATION ............................................. 32 


\section{TABLES}

1. Cost Estimates in Comparing Flexible Package Cells (Flex) and Rigid

Cells (Rigid).

A.1. Selected Input Parameters for Design Study 18

A.2. Comparison of Parameters for Baseline Flexible Packaging and Rigid Cells for 25-kW Hybrid Vehicle Batteries

B.1. Thermal Management Parameters for 25-kW Hybrid Vehicle Batteries with Flexible Package Cells 27

\section{FIGURES}

1. Lithium-Ion Flexible Packaging Cell (Flex Cell) ............................................... 4

2. Lithium-Ion Cell in Deep-Drawn Aluminum Container (Rigid Cell) .......................... 4

3. Cell with Rigid Container and Heat-Sealed Terminals............................................. 6

4. Terminal/Core Assembly for Flexible Package Cell ….......................................... 7

5. Terminal/Core Assembly for Rigid Aluminum Container ......................................... 7

6. Connection of Current Collector Foils to Flat Terminals Using Stapled

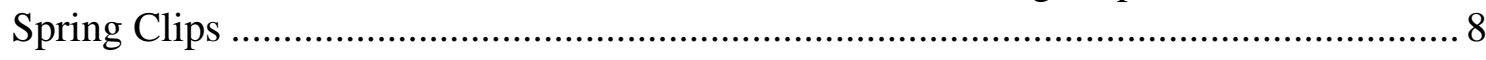

7. Three-Piece Rigid Container for Lithium-Ion Cell................................................. 10

8. Two-Piece Rigid Container with Closure on Side of Cell ........................................ 10

9. One-Piece Aluminum Cell Cover. Cover Stamped from Aluminum Sheet to

Provide Flow Channels for Coolant and Support for Flexible Cell Package ................. 12

10. Rigid Cell with Sleeve that Provides Cooling Passages Between Adjacent

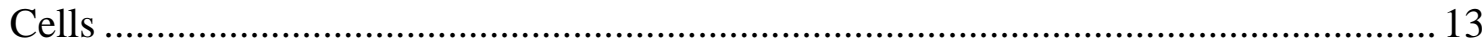

11. Module of Twenty Flexible Package Cells Showing Coolant Flow Pattern ................. 14

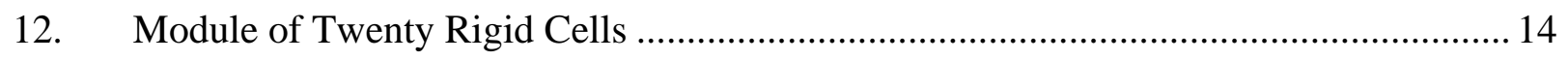




\section{FIGURES}

A.1. Effect of Number of Wraps on the Width and Thickness of 20-Ah Flex Cells............. 19

A.2. Correlation of Results Calculated by the Partial Differential Equation System (Flex PDE.4.0.6a by PDE Solutions, Inc.)

A.3 Breakdown of Battery Resistance for Baseline Flex Cells and Rigid Cells .................. 22

A.4. Cross-Section of Flex Cell Module Showing Flow Coolant Flow Passages ................. 23

A.5. Insulated Battery Jacket Providing Cooling with Transformer Fluid............................ 23

A.6. Weight and Volume of 25-kW Batteries of Flex Cells or Rigid Cells ........................ 23

A.7. Weight Breakdown for 25-kW HEV Batteries of Baseline Design............................. 24

B.1. Heating of Battery during Standby for Various Ambient Temperature ........................ 26

B.2. Temperature Rise Above that of Adjacent Coolant for Flex Cells .............................. 27

B.3. Maximum Temperature Reached at Center of Flex Cell during Malfunction that Converts Electrochemical Energy of Fully Charge Cell to Heat at C/1 Rate with Coolants at $10^{\circ} \mathrm{C}$ Inlet Temperature 28

B.4. Maximum Temperature Reached at Center of Base Line Flex Cell (23 wraps) as Function of Heat Generation Expressed as the Time to Convert the Total Electrochemical Cell Energy to Heat with Coolants at $10^{\circ} \mathrm{C}$ Inlet Temperature 


\section{ACKNOWLEDGEMENTS}

This work was supported by the U.S. Department of Energy's FreedomCAR \& Vehicle Technologies Program with the direction of Tien Duong and David Howell of that Program. We especially thank Steven W. Cornell, Plastic Partners, Naperville, Illinois, for design suggestions, arranging meetings with experts at container manufacturers and reviewing this report. Design suggestions and assistance in estimating costs were provided by Takehiro Hosokawa of Sumitomo Electric Flat Components, Inc.; Michael R. Gredlics and Len Jenkins of Crown Packaging Technology, Alsip, Illinois; James Rinehart of Integrated Solutions, Waukegan, Illinois; and William J. Reimann of Flex-Packaging, Inc., Batavia, Illinois. Dennis Dees, Argonne, assisted in calculating the electrical resistance of the cell current collection systems. Gary Henriksen supervises Argonne’s Battery Technology Department. 


\section{GLOSSARY OF TERMS}

Argonne

ASI

Double seaming

Flex cell

LBW

Rigid cell

TIG welding
Argonne National Laboratory

Area specific impedance (ohm- $\left.\mathrm{cm}^{2}\right)$

Mechanical closure for containers that performs a crimp by double folding the container and cover and is commonly used on food "cans."

Flexible multi-laminate containment package

Laser beam welding

Metal cell container

Welding procedure performed in an inert gas atmosphere using a tungsten electrode 


\section{EXECUTIVE SUMMARY}

We conducted a design study to compare the manufacturing costs at a level of 100,000 hybrid vehicle batteries per year for flexible package (Flex) cells and for rigid aluminum container (Rigid) cells. Initially, the Rigid cells were considered to have welded closures and to be deep-drawn containers of about the same shape as the Flex cells. As the study progressed, the method of fabricating and sealing the Rigid cells was expanded to include lower cost options including double seaming and other mechanically fastened closures with polymer sealants. Both types of batteries were designed with positive electrodes containing $\mathrm{Li}\left(\mathrm{Ni}_{1 / 3} \mathrm{Co}_{1 / 3} \mathrm{Mn}_{1 / 3}\right) \mathrm{O}_{2}$ and graphite negative electrodes. The use of a different combination of lithium-ion electrodes would have little effect on the difference in costs for the two types of cells. We found that 20-Ah cells could be designed with excellent performance and heat rejection capabilities for either type of cell. Many parts in the design of the Flex cells are identical or nearly identical to those of the Rigid Cell, so for these features there would be no difference in the cost of manufacturing the two types of batteries. We judged the performance, size and weight of the batteries to be sufficiently similar that the batteries would have the same value for their application.

Some of the design features of the Flex cells were markedly different than those of the deep-drawn and welded Rigid cells and would result in significant cost savings. Fabrication and processing steps for which the Flex cells appear to have a cost advantage over these Rigid cells are (1) container fabrication and sealing, (2) terminal fabrication and sealing, and (3) intercell connections. The costs of providing cooling channels adjacent to the cells and for module and battery hardware appear to favor Rigid cell batteries slightly. Overall, Flex cell batteries appear to have an advantage of about $\$ 1.20-\$ 3.70$ per cell for a $25-\mathrm{kW}$ Battery of 20 cells or about $\$ 24$ to $\$ 74$ per battery.

Container experts assisted with this study, including a paid consultant and personnel at container manufacturing companies. Some of the companies are considering entering the business of manufacturing containers for hybrid vehicle battery manufacturers. For this reason they provided valuable guidance on overall approaches to reducing the costs of the cell containers. They have retained the description of some specific designs and procedures for future possible work with battery manufacturers, with whom they are now in contact.

Through the guidance of these experts, we determined that a new type of container could be manufactured that would have the best features of performance and low cost of both the Rigid and Flex containers. For instance, the aluminum layer in a tri-layer sheet can be sufficiently thick to form a rigid container that can be fabricated in two halves, much like a Flex container, and mechanically joined at the edges for strength. In addition to the mechanical joint, this container can be sealed at the edges, much like a Flex container, by means of an inner polymer liner that can be heat-sealed or ultrasonically welded. The terminals can be flat strips of metal sealed into the top of the container as part of the edge sealing of the container, as for the Flex cell. Ridges can be stamped into one side of the container to provide cooling channels and the exterior layer of the container stock can be coated with a thin, electrically insulating, polymer layer. We expect this type of container will provide excellent sealing and durability and be less expensive than either the Flex or the Rigid container, which the study initially considered. 
A major cost for the original Rigid container is the welding required for sealing the container. However, the welding of the current collector tabs to the terminal piece may be even more complex and costly than welding the container. It is important, therefore, to develop an inexpensive procedure for attachment of the foils to the terminal pieces. A lower-cost procedure, such as ultrasonic welding or mechanical clipping, might replace laser welding of the foils to the terminal pieces.

A conclusion from our discussions with the container experts is that the manufacturing rate required for the containers for hybrid vehicle batteries is fairly low, and thus favors procedures requiring low tooling costs and little development effort. These conditions favor flexible packaging, heat sealing, shallow stamping, double seaming and ultrasonic welding. It works against deep drawing and untested procedures for welding and joining. 


\section{INTRODUCTION}

A previous report [1] described the concept of replacing the rigid container used for prismatic lithium-ion cells with a flexible multi-laminate containment package of a type commonly used in the food packaging industry. That report described testing procedures and preliminary results that were used to set the test criteria and target values that are required to achieve a 15-year life for the flexible packaging container for the battery application.

The purpose of this study was to compare the costs of producing a hybrid vehicle battery of flexible package (Flex) cells and a similar battery of cells with deep-drawn aluminum containers (Rigid cells). A complicating factor is that neither Flex cell nor Rigid cell batteries have been designed in sufficient detail for accurate cost estimates, which would require quotes from processing equipment manufacturers and the determination of manufacturing space and personnel requirements. The complexity of the task was reduced by designing similar Flex and Rigid cells so that it was only necessary to estimate the costs of those cell and battery characteristics that differed significantly to obtain an overall estimate of the difference in the costs of manufacturing the two types of batteries.

The design effort included both the sketching of cell and battery configurations, which are described below, and the calculating of performances of 25-kW hybrid vehicle batteries, which is described in detail in Appendix A, Design Modeling. Both types of batteries were designed with positive electrodes containing $\mathrm{Li}\left(\mathrm{Ni}_{1 / 3} \mathrm{Co}_{1 / 3} \mathrm{Mn}_{1 / 3}\right) \mathrm{O}_{2}$ and graphite negative electrodes. The selection of other lithium-ion electrode materials would not be expected to affect the difference in costs of the two types of batteries. Design and calculation of the performance of the entire batteries was necessary because the design of the cells could impact the design and cost of module and battery hardware.

The overall strategy for saving cost with flexible packaging versus the use of deep-drawn aluminum containers is the following:

- $\quad$ Reduce the cost of the container fabrication.

- Seal the terminals and container in one quick step with a low-temperature $\left(215^{\circ} \mathrm{C}\right)$ sealing operation.

- Substitute a low-cost method for the laser welding of current collectors to terminal pieces.

- Simplify the terminals by the use of flat metal strips.

- Simplify the interconnection of cells.

The designs of the two types of cells reflected the above strategy, but where applicable, advances proposed for the Flex cell were also applied to the Rigid cell, such as attaching the current collector foils to the terminal piece by a low-temperature, low-cost method instead of by laser welding.

One approach to reducing the overall cost of the battery is to use a small number of moderately large cells in the battery and thus reduce the costs of cell and battery hardware, monitoring devices, and the state-of-charge equalization controller. After preliminary 
calculations we found that cells of 20-Ah capacity could be designed with a thin cross-section (about $14 \mathrm{~mm}$ thick) and this cell size, which requires only 20 cells for a 25-kW battery, was selected as the standard for this study. Sketches of the Flex cells and Rigid cells of this study are shown in Figures 1 and 2, respectively.

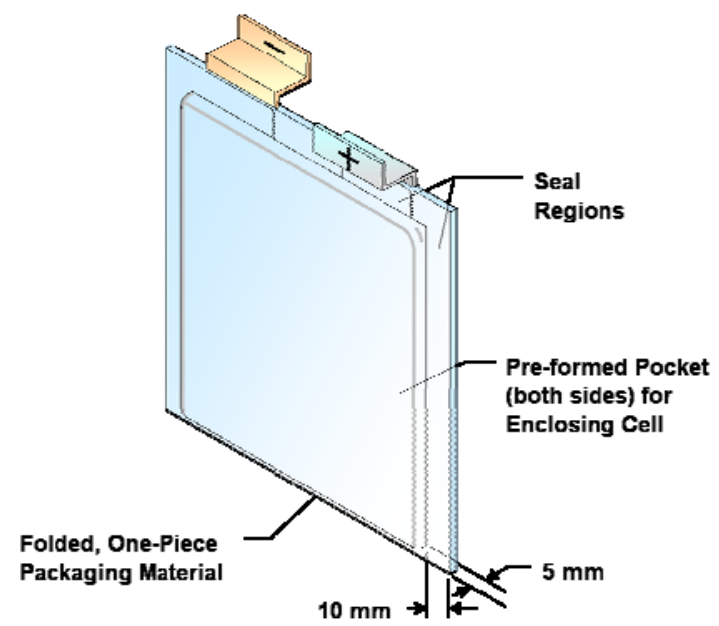

Fig. 1. Lithium-Ion Flexible Packaging Cell (Flex Cell)

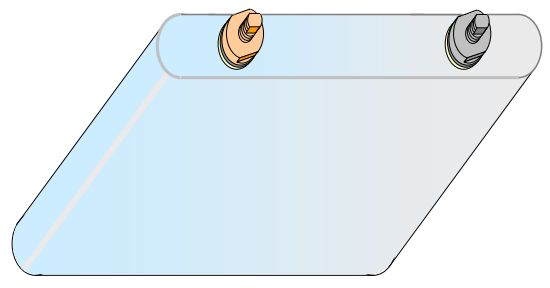

Fig. 2. Lithium-Ion Cell in Deep-Drawn Aluminum Container (Rigid Cell)

Good temperature control for the lithium-ion battery is important for long life, safety, and power after startup in very cold weather. Provision must be made for coolant passages between cells and this is a special problem for the Flex cells, for which the container material is not sufficiently rigid and creep-resistant to be configured for coolant passages. A dielectric fluid, such as a transformer fluid, is a better coolant than air, especially during a cell malfunction when the rate of thermal energy generated within the cell may be many times the normal rate. The use of a dielectric coolant has an added advantage in that it serves to hinder the transfer of moisture into the cell through the polymer seals of the terminals and container closures and, likewise, to hinder diffusion of solvent vapor out of the cell. In Appendix B, Thermal Management, thermal management issues that are only indirectly related to the relative costs of the two types of cells are discussed and the advantages for a dielectric coolant are considered. In that section we present our conclusions that, on the basis of its improved thermal performance alone, a dielectric coolant could be justified versus air coolant for use in both types of batteries. 
The attractiveness of lithium-ion batteries for the hybrid vehicle application is based upon very high power capability, high specific energy, moderate electrode costs, and prospects for long life. Potential disadvantages, which must be met at low cost for success, are the need for (1) electronically controlled state of charge equalization for each cell and (2) avoidance of a temperature runaway resulting from excessive heat generation caused by cell or control system malfunctions. These require careful monitoring of voltage and temperature at each cell for control purposes and for early warnings of cell malfunctions. Pressure sensors for each cell can also be provided as discussed below. More detail on these subjects is presented in Appendix C, Safety and Monitoring.

During this cost study, we consulted container experts to assist us in assessing costs and to guide us in selecting designs for study. Stephen W. Cornell, a paid Argonne consultant who previously directed research and development for major container manufacturers, assisted us in selecting designs for study and in arranging visits with personnel from several firms involved in container development and manufacturing. These personnel included, Len Jenkins, Vice President, and Michael R. Gredlics of Technology Development, Crown Packaging Technology, Alsip, Illinois; William J. Reimann, President of Flex-Pak, Inc., Batavia, Illinois; and James Rinehart, Co-owner of Integrated Solutions, Waukegan, Illinois.

The personnel from Crown directed our attention to a rigid container design that combines the main performance and cost advantages of both the Rigid and Flex designs. An approximate sketch of this design is shown in Figure 3. Because this new approach came rather late in the study, the costs of the Rigid and Flex cells are discussed without regard to this design in the sections below and then the new approach is discussed separately in Section 4, Rigid Container with Polymer-Sealed Terminals. 


\section{COST COMPARISON}

\section{$2.1 \quad$ COST OF FABRICATION OF CELL WINDINGS}

Both the Flex and the Rigid container designs employ a flat-wound cell configuration, which is fabricated by wrapping bicell sheets around a flat core. The bicell sheets consist of negative electrode coatings on both sides of a copper current collector foil, a separator sheet, positive coatings on both sides of an aluminum foil, and a second separator sheet. The copper foil extends beyond the coatings and the separator sheets at the top of the cell and the aluminum foil extends beyond the coatings and separator sheets at the bottom of the cell to facilitate attachment of the current collector sheets to the terminal pieces or their extensions.

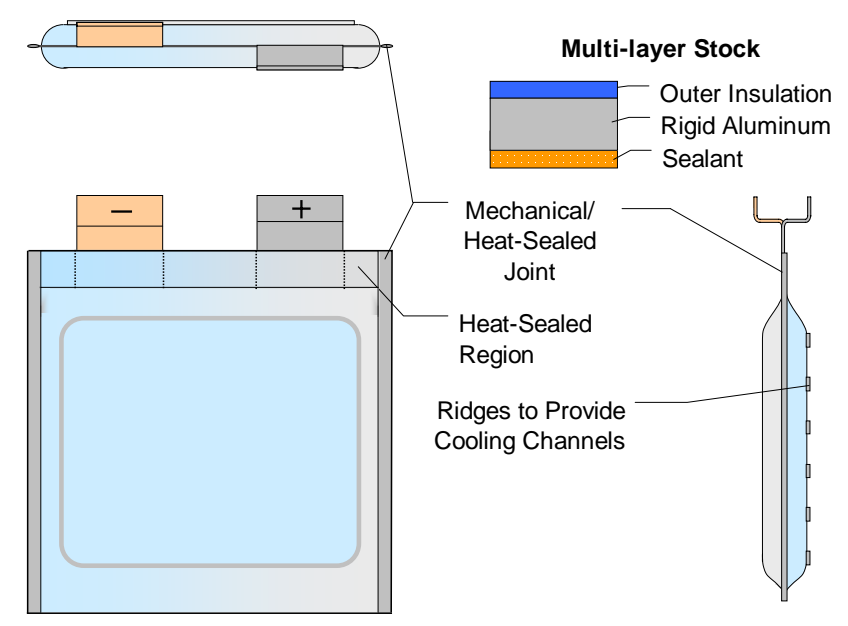

Fig. 3. Cell with Rigid Container and Heat-Sealed Terminals

The cores about which the windings are wrapped are polymer plates with recesses to receive the terminal pieces that are fastened to them (Figs. 4 and 5). Even though the terminal pieces are different for the two types of cells, there is very little difference in the handling of the core assemblies during the cell winding operation. In both cases the terminal pieces would probably be in place during winding, although they might be slipped into place after the winding for either cell type, if that would facilitate the winding operation.

The Rigid cell has only slightly more (1.4\%) cell area than the Flex cell to balance the higher resistance in the Rigid cell terminals and connections (Appendix A, Design Modeling). These nearly identical cell areas result in insignificant differences in the dimensions of the cell windings. The number of cell wraps is largely responsible for determining the thickness of the cells. The Flex cell thickness is limited by the maximum thickness that can be enclosed in an economical flexible package and the Rigid container must be thick enough to accommodate a cylindrical feedthrough. A cell thickness of 12 to $14 \mathrm{~mm}$ is near optimum for both designs and was selected as a target. 


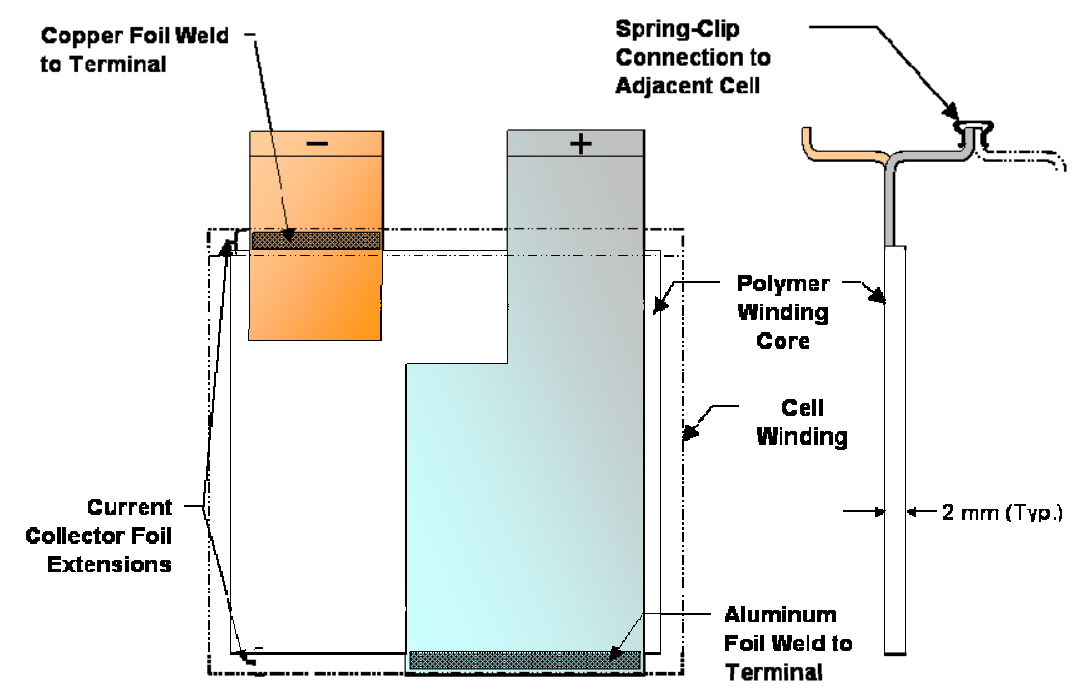

Fig. 4. Terminal/Core Assembly for Flexible Package Cell

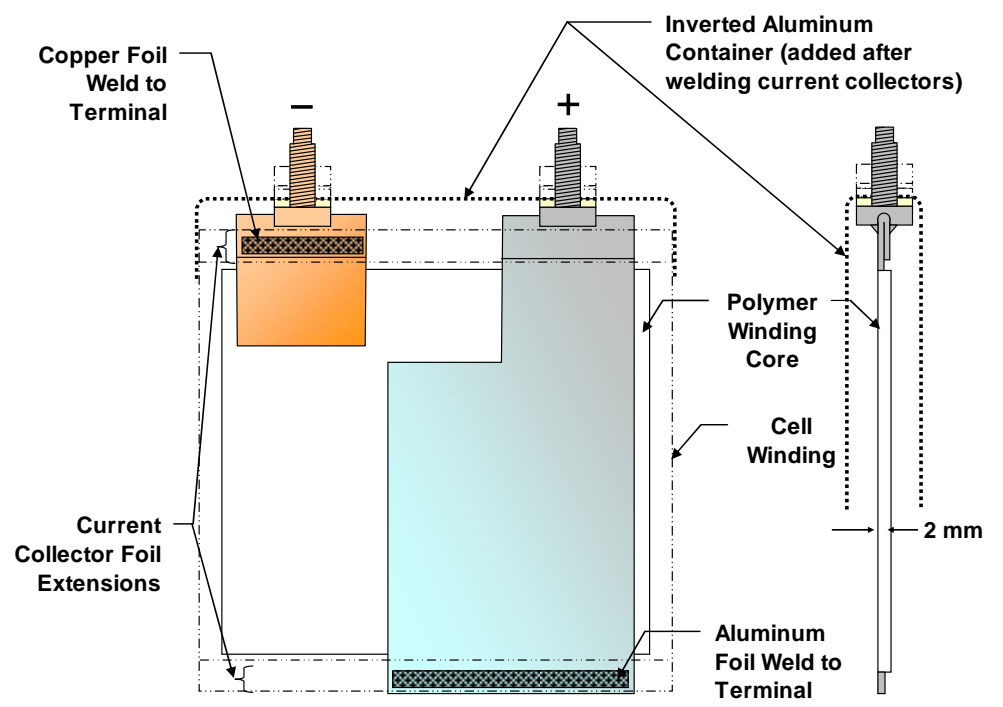

Fig. 5. Terminal/Core Assembly for Rigid Aluminum Container

With 23 windings around the cell core, both types of cells are about $14 \mathrm{~mm}$ thick and, therefore, 23 was selected as the number of windings for the baseline cells of both types. The thin cross-section of these cells results in excellent heat rejection characteristics.

Since the windings are so similar, no cost difference for the winding materials or fabrication of the windings is expected for the two methods of cell packaging under consideration. This resulted in great simplification of the cost study because the cost of the winding materials and fabrication are difficult to assess without detailed designs, detailed fabrication procedures, and well established manufacturing equipment. 


\subsection{COST OF ATTACHMENT OF ELECTRODES TO TERMINALS}

One of the low-cost packaging features we sought is the avoidance of high-temperature welding of the current collector foils to the terminal pieces. Because of the sensitivity of the electrodes and separators to high temperature, the high-temperature welding technique of choice has been laser beam welding (LBW) for which high temperature can be confined to a small region. In welding single tabs or larger pieces LBW is effective, but work at Mine Safety Appliances Company on 50-Ah lithium-ion cells, found that the simultaneous welding of many foils of aluminum to a terminal piece resulted in porosity and voids in the welds [2]. A promising cold welding technique for attachment of electrode foils to the terminals is ultrasonic welding. In the Mine Safety Appliances study, ultrasonic welding of 10 foil tabs to a single feeder tab was successful, resulting in connections with very low resistance [2]. Welding of as many as 23 foils on each side of the terminal piece as required by the designs for the 20-Ah baseline cells of this study is believed to be feasible with a moderate development effort and, potentially, to have low cost in production.

Another approach that should be considered is attachment using specially designed spring clips to attach both the positive current collectors at the bottom of the cell and the negative current collector foils at the top of the cells to their respective terminal pieces (Fig. 6). This approach would require experimentation to determine if insulating layers build up between the attached metal parts under cell operating compositions and potentials, which would cause increasing cell resistance. If it can be shown that connections of this type can be made with low resistances over a long life, this method of attachment could be rapid and result in low costs for mass production.

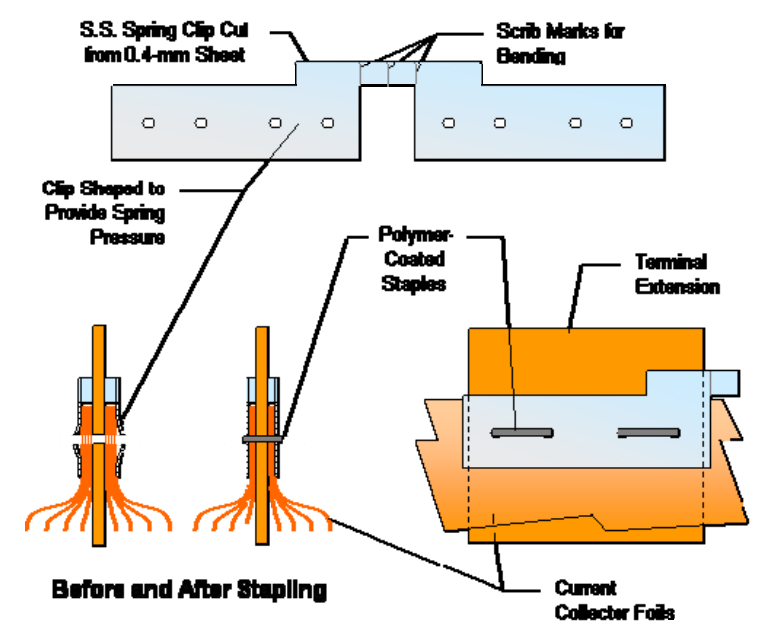

Fig. 6. Connection of Current Collector Foils to Flat Terminals Using Stapled Spring Clips

The designs for the winding assemblies for the flexible packaging cells and the rigid container cells are very similar. Whichever technique for attachment of the current collector foils to the terminals is employed for one packaging approach will work equally well for the other. As a result, no cost difference for attaching the current collector foils to the terminal pieces is expected for the two packaging methods. However, the success in finding an excellent 
low-cost method of current collector attachment is vital for the overall success in developing a low-cost lithium-ion battery.

\section{$2.3 \quad$ COST OF CONTAINER FABRICATION AND SEALING}

The greatest differences between the two packaging approaches are in the fabrication and the sealing of the packages themselves (Figs. 1 and 2). The flexible package material is made in sheets that can be used for containers of any desired dimensions and even for batteries for more than one application. The usefulness of the same flexible packaging for cells of different sizes is especially important at low production rates and when the cell size has not been standardized. Pressing a pocket into both sides of the flexible packaging sheet that is to enclose the cell may be advantageous for accommodating the thickness necessary for the cell winding. This pocket formation has already been done without difficulty in test cells made for Argonne by Sumitomo Electric Industries, LTD [1]. The tooling required for forming the pocket to receive the winding is simple and inexpensive.

A concern that must be addressed for the flexible packaging is the effectiveness of measures to prevent diffusion of moisture into the package and diffusion of electrolyte solvent out of the package. Two layers of aluminum are effective in blocking diffusion through the side walls, but diffusion through the seal area is equally important. Calculations based on published values of the permeability coefficients through the polymer sealant materials [3] indicate that, with care in the design, the seals of both types of cells will sufficiently block the diffusion of water and organic solvents to achieve 15-year life. The use of a hermetically sealed battery pack, such as can be done if a silicone transformer coolant is used as is proposed for both cell packaging approaches, would serve as an additional barrier to hinder the ingress of water and air.

The rigid aluminum container requires tooling for fabrication that is unique for the particular dimensions of the container. The cost of this tooling depends on the container design. The most expensive design is a deep-drawn container (Fig. 2). It is apparent that at very high production rates of a standard size, for instance 12-oz beverage containers, deep-drawn aluminum containers can be quite inexpensive. For moderate production rates of 2,000,000/yr (100,000 20-cell batteries/yr), the market for the container supplier would be $\$ 2,000,000 / \mathrm{yr}$ at $\$ 1.00$ per cell container. At that moderate production rate, the tooling development, setup and retooling costs might be a significant fraction of the total revenue to the supplier. Also, even slight changes in cell size would result in a loss of the inventory of finished containers and the need to retool. A starting rough estimate cost of $\$ 1.00 /$ cell to the battery manufacturer was deemed plausible for deep-drawn aluminum containers and matching covers.

A thin cell design, while advantageous for cooling, would present a difficulty for the Rigid cell in welding the cover to the container near the terminals. We propose that the container be slipped on from above the winding and that the closure be made at the bottom of the cell (Figs. 2 and 5). This approach requires holes in the "bottom" of the inverted container to receive the terminals.

An alternative to welding for closing the container is crimping by double seaming, as is done for food "cans." Double seaming is an inexpensive method of closing a container and 
makes it possible to circumvent deep drawing. A three-piece container can be constructed by double seaming both the top and the bottom of the container that has a body constructed by bending and welding a flat sheet (Fig. 7), which is similar to the construction of a container for machine oil. A two-piece container can be constructed from a shallow-drawn container with a double-seamed closure on the side of the container (Fig. 8) similar to the construction of a sardine can. The three-piece container is more commonly made from steel because the required weld is more easily done with steel (stainless steel would be required for the battery cell) and the two-piece container is more commonly made with aluminum, which is more easily drawn than steel.

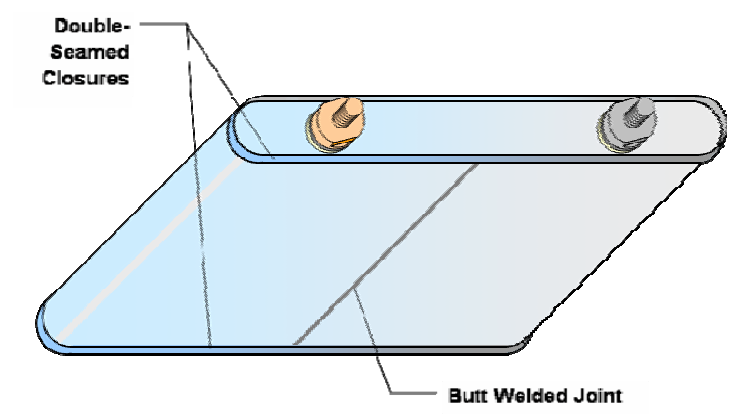

Fig. 7. Three-Piece Rigid Container for Lithium-Ion Cell

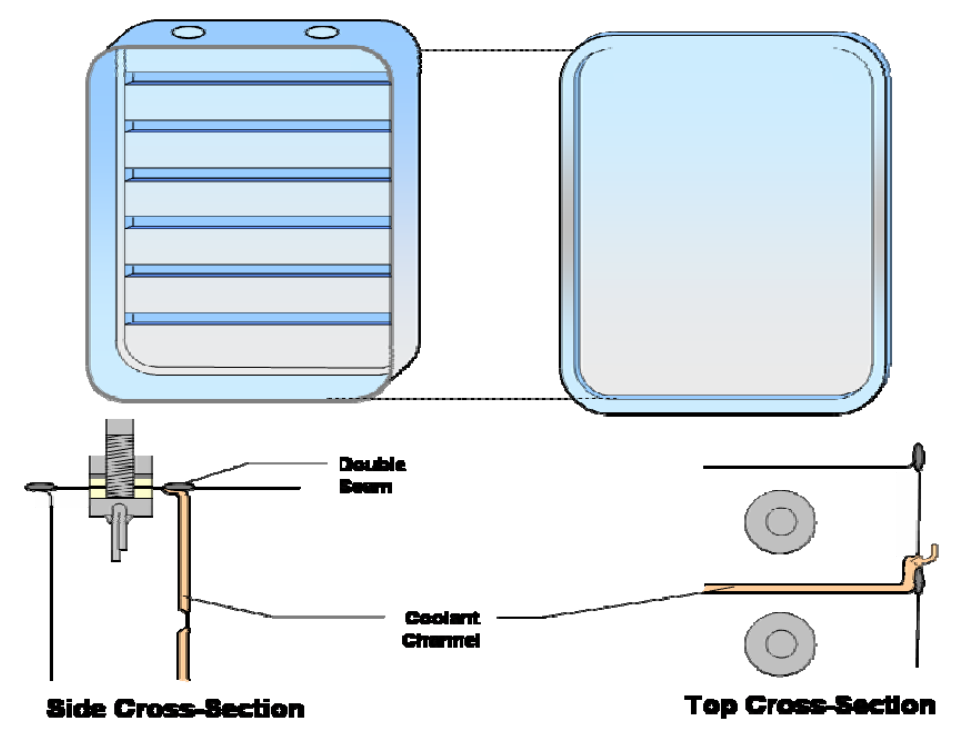

Fig. 8. Two-Piece Rigid Container with closure on Side of Cell

The cost of fastening the cover onto the cell would be most expensive for laser welding (assume \$2.00/cell), less expensive for TIG welding (\$1.50/cell), and least expensive for double seaming ( $\$ 0.50 /$ cell). Double seaming might also save an additional $\$ 0.50 /$ cell in the cost of the container by avoiding the need for deep drawing.

Flexible packaging has a substantial cost advantage over rigid containers both in fabrication of the container and in sealing the container. This advantage for the Flex cells would 
be enhanced for a manufacturing facility that produced cells of several different sizes or occasionally changed the size of a cell. Although Rigid cell size requires retooling, a single stock of flexible packaging material will suffice for a wide range of Flex cell sizes and the pressing of pockets to receive the winding, if necessary, would require inexpensive tooling. The material cost, including formation of pockets to receive the windings, was estimated by a Japanese vendor in the flexible packaging industry at $\$ 0.40 /$ cell. Sealing is estimated to cost an additional $\$ 0.20 /$ cell.

\subsection{COST OF TERMINAL FABRICATION AND SEALING}

The terminals for the Flex cells can be fabricated from sheet or strip stock. In the design study, the terminals were made of 1-mm-thick materials. Prior to cell assembly, it might be desirable to bend the terminals so that the negative and positive terminals of adjacent cells will be aligned for cell interconnection (Figs. 1 and 4). A set of terminals was estimated to cost $\$ 0.40 /$ cell by the Japanese vender mentioned above. The sealing of the terminals into the flexible package is not a separate operation, but is accomplished during sealing of the package. The seam in the top of the package through which the terminals extend is sealed by hot sealer jaws that are shaped to accommodate the terminals [1]. These procedures have already been demonstrated for Argonne by Sumitomo [1].

In contrast to the simplicity of fabricating and sealing the Flex cell terminals, the Rigid cell will require the development of new fabrication and sealing procedures. The most straightforward approach to terminal fabrication for the Rigid cell is to weld the sheet stock, to which the current collector foils will be attached, to the terminal feedthrough. The terminal feedthrough would have a threaded stud so that a seal could be made with the container by means of gaskets on both sides of the container that are compressed by tightening a nut (Figs. 2 and 5). To minimize moisture intrusion, the gasketing material could be annealed nickel with a thin insulator adjacent to the container. In Figure 5, the terminal feedthrough is shown as a threaded stud with flats at the top of the threaded region so that it might be gripped when the nut is tightened to seal the unit. In order to improve electrical conductivity, the sheet stock is folded at the top where it is welded to the stud. Various approaches could be taken to developing improved terminals for Rigid cells. Single forged pieces might be developed that provide the function of the metal strip for attachment of the current collector's foils and the function of the threaded feedthrough, thus avoiding the welding of these parts together. A special container top could be developed that seals directly to flat terminal strips similar to the sealing mechanism used for the terminals of the Flex cells.

Although the exact costs for the terminals have not been determined, it seems unlikely that development efforts will reduce the costs of the terminal fabrication and sealing for the Rigid cell to those for the Flex cell, which employs only flat strips and no special sealing procedures except as a part of the cell sealing. The cost of fabricating terminals for rigid cells and sealing them into the top of the container is estimated to be $\$ 1.50$ to $\$ 2.00 /$ cell, depending on the terminal design and the success of the development efforts. 


\subsection{COST OF PROVISION FOR COOLING CHANNELS}

Provision for cooling channels adjacent to the cells is important both for normal temperature control of the cells and as a safety measure during an internal short circuit, when a high cooling rate is desirable to avoid a more serious temperature excursion. Cooling with a dielectric transformer fluid that can withstand high temperatures would be more effective than air cooling. Cooling with air is less expensive, but not as safe. Both methods of cooling require attention to the thickness of the cooling channel for efficient cooling and acceptable pressure drop in the coolant circuit. The coolant is in laminar flow through thin, broad channels (about $1 \mathrm{~mm} \times 20 \mathrm{~mm})$ so that the Nusselt number $(\mathrm{Nu})$ is about 8.24. $\left(\mathrm{Nu}=\mathrm{hD}_{\mathrm{h}} / \mathrm{k}\right.$, where $\mathrm{h}=$ heat transfer coefficient, $\mathrm{D}_{\mathrm{h}}=4 \mathrm{x}$ flow area/perimeter, and $\mathrm{k}=$ thermal conductivity, all in consistent units.) Thus, the heat transfer coefficient at the surface of the cell is inversely proportional to the thickness of the cooling channel. Considering both pressure drop and cooling efficiency, the appropriate cooling channel thickness was found to be about $1.0 \mathrm{~mm}$ for both air and dielectric fluid.

Flex cells do not provide rigid surfaces for the walls of cooling channels. We propose to circumvent this problem by stamping rigid aluminum plates and folding them to enclose the flexible cells, and also to provide horizontal cooling channels (Fig. 9). These cell covers would be about the same thickness $(0.4 \mathrm{~mm})$ and weight as the Rigid cell containers, but much less expensive because they are rapidly formed by shallow pressing with simple tooling. Their estimated cost is $\$ 0.50 /$ cell.

Cooling channels for the Rigid cell are easily made by means of a polymer sleeve that slides over the cells to provide horizontal cooling channels (Fig. 10). These sleeves could be made by stamping a polymer sheet for about $\$ 0.20 /$ cell. We propose that the cooling channels be provided for the "sardine can" design in the shallow drawing step (Fig. 8), but no additional savings is assumed because of the difficulty in comparing the overall cost of this design with that of the three-piece design, which would probably require a polymer sleeve to provide cooling channels.

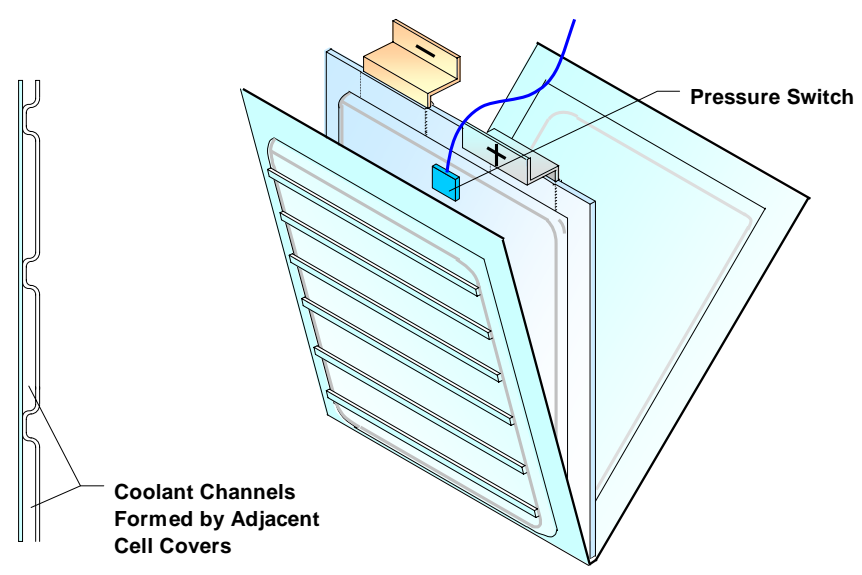

Fig. 9. One-Piece Aluminum Cell Cover. Cover stamped from aluminum sheet to provide flow channels for coolant and support for flexible cell package. 


\subsection{COST OF PRESSURE RELIEF AND PRESSURE SENSING}

Many safety features need to be included in a realistic lithium-ion battery design. Battery safety is discussed in more detail in Appendix C, Safety and Monitoring.

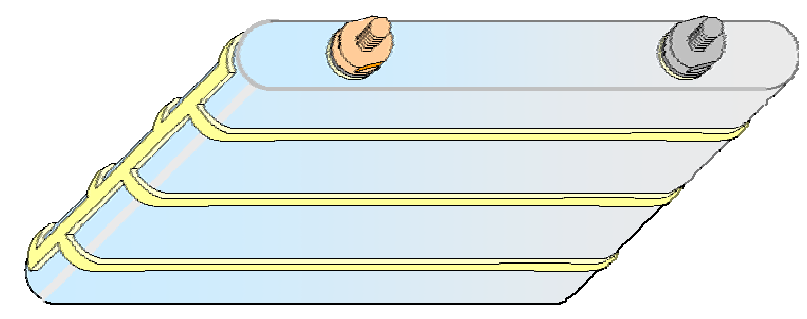

Fig. 10. Rigid Cell with Sleeve that Provides Cooling Passages between Adjacent Cells

Sensors measuring voltage and temperature are important for state-of-charge control and for taking action to avoid damage to the battery and the vehicle from, for instance, a malfunctioning battery controller, which may result in overcharging. An inexpensive pressure switch, if necessary, could be located outside of either the Flex cells or the Rigid cells to actuate a breaker to open the circuit in case of high pressure within a cell. All of these devices and those that they actuate to protect the battery would have about the same cost for both systems, and thus no difference in the cost of sensors is estimated for the two systems.

The cost of providing pressure relief, which is usually done by scoring the top or the bottom of rigid containers, is estimated to be $\$ 0.10$ per cell. A similar method for weakening the side of a Flex container needs to be developed. Pressure relief through the seals of flexible packaging containers has been shown to take place over too wide a pressure range to be reliable. The total cost for providing both a pressure switch and pressure relief is estimated to be about the same for Rigid cells and Flex cells.

\subsection{COST OF INTERCELL CONNECTIONS}

Forming a series connection of cells is easily done with Flex cells because the flat terminals can either be connected by ultrasonic welding or by use of a spring clip (Fig. 4). The state-of-charge equalizing system can also be connected during either of these procedures. This can be done, for instance, by pre-connecting the spring clips to the state-of-charge controller so that the connection to that device is automatically made when the spring clips are attached to the terminals (Fig. 11). For Flex cells, the cost of spring clip connectors and their attachment or ultrasonic welding of the terminals is estimated to be $\$ 0.20 /$ cell.

The threaded terminals of the Rigid cells require the use of a separate connector that is fastened to the terminals by threaded nuts. The connectors can be imbedded in a polymer plate that is attached to the state-of-charge controller and leads in this plate result in automatic connection of the cells to the controller (Fig. 12). The cost of the connectors imbedded in the 
polymer plate and the attachment of this assembly to the terminals of the Rigid cells is estimated to be $\$ 0.50$ / cell. This cost does not include that for the state-of-charge controller, which would be the same for both types of batteries.

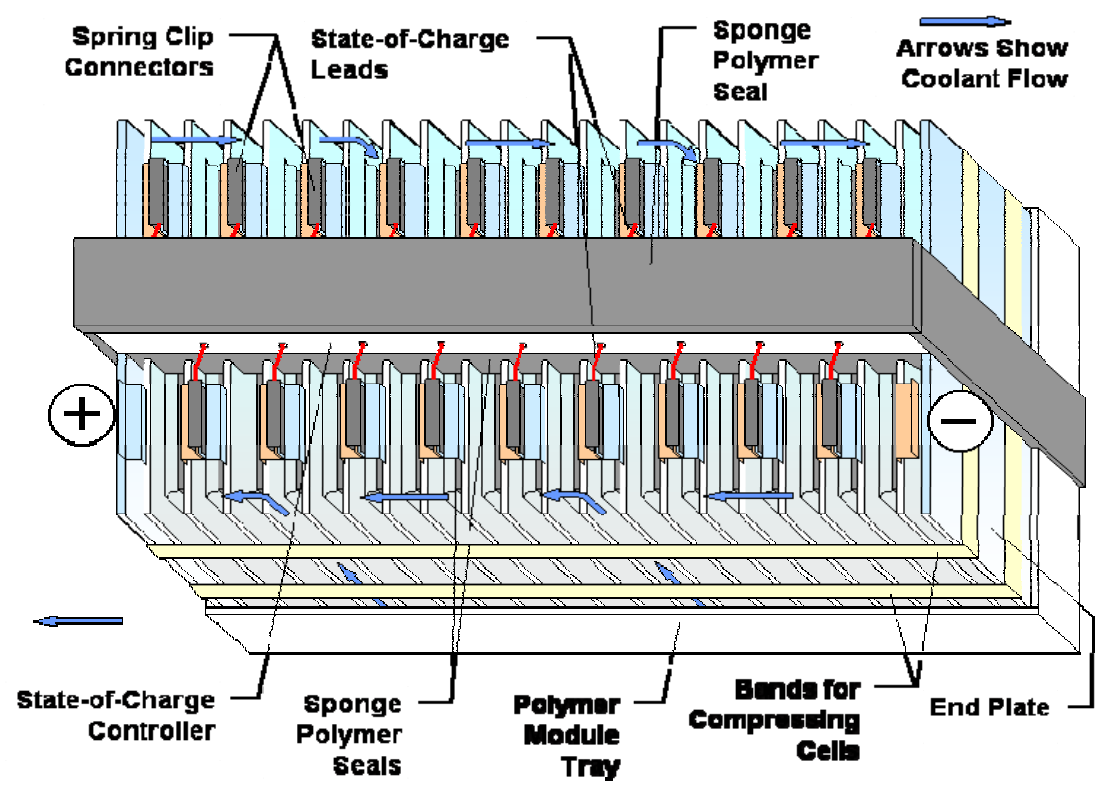

Fig. 11. Module of Twenty Flexible Package Cells Showing Coolant Flow Pattern

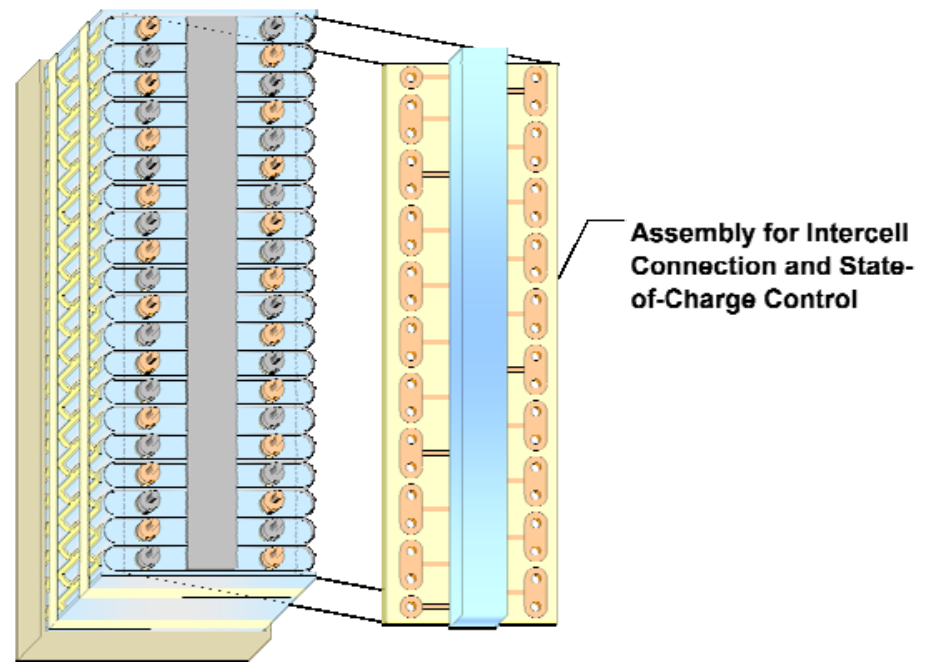

Fig. 12. Module of Twenty Rigid Cells

Overall, the Flex cells appear to have a cost advantage over the Rigid cells in making intercell connections because the Flex cell terminals can be connected directly without the need for an additional connector piece. Bolted connections or spring clip connections may oxidize, and are more likely to require maintenance than welded connections. If welding of the intercell 
connectors is required to achieve 15-year life, it can be done more easily by ultrasonically welding of the flat Flex cell terminals than by any welding procedure for the Rigid terminals.

\subsection{COST OF MODULE AND BATTERY HARDWARE}

The module and battery hardware can be practically identical for the two types of cells. The volume of the baseline Flex battery would be about three liters larger (28\%) than that of the Rigid cell battery; about half of that volume is due to the extra coolant volume in the space near the seals. The weight breakdown for the battery parts for the two systems is shown in Figure 19. If air cooling were used, there would be very little difference in the total weights of the two types of batteries. With dielectric coolant there is a slight additional cost for the additional materials in the Flex cell battery (mostly additional coolant cost) of about $\$ 6.00$ or $\$ 0.30 /$ cell for a 20-cell battery. 


\section{COMPARATIVE COST SUMMARY}

Overall, Flex cell batteries appear to have an advantage of about $\$ 1.20-\$ 3.70$ per cell for a $25-\mathrm{kW}$ Battery of 20 cells, or about $\$ 24$ to $\$ 74$ per battery. The estimated cost advantages discussed above are summarized in Table 1.

Table 1. Cost Estimates in Comparing Flexible Package Cells (Flex) and Rigid Cells (Rigid)

\begin{tabular}{|l|c|c|l|}
\hline \multirow{2}{*}{} & Cost, \$/cell & \multicolumn{2}{|c|}{} \\
\cline { 2 - 3 } & Rigid & Flex & Difference $^{\mathbf{a}}$ \\
\hline Fabrication of cell windings & $\mathrm{b}$ & $\mathrm{b}$ & $\$ 0.00$ \\
\hline Attachment of electrodes to terminals & $\mathrm{C}$ & $\mathrm{C}$ & 0.00 \\
\hline Container fabrication and sealing & $\$ 1.00-3.00$ & $\$ 0.60$ & $0.40-2.40$ \\
\hline Terminal fabrication and sealing & $1.50-2.00$ & 0.40 & $1.10-1.60$ \\
\hline Provision for cooling channels & 0.20 & 0.50 & $(0.30)$ \\
\hline Pressure relief and pressure switch & $\mathrm{d}$ & $\mathrm{d}$ & 0.00 \\
\hline Intercell connections & 0.50 & 0.20 & 0.30 \\
\hline Module and battery hardware & $\mathrm{e}$ & $\mathrm{e}+0.30$ & $(0.30)$ \\
\hline Total cost advantage for Flex cells & & & $1.20-3.70$ \\
\hline
\end{tabular}

a Cost for Rigid Cells minus that for Flex cells

b Cost of materials and fabrication for Rigid windings

c Cost of attaching Rigid cell electrodes to terminals

d Cost of providing pressure relief and a pressure switch for Rigid cell

e Cost of module and battery hardware for Rigid cells 


\section{RIGID CONTAINER WITH POLYMER-SEALED TERMINALS}

As noted in Section 1, Introduction, personnel from Crown Packaging Technology suggested, late in our study, a design (Fig. 3) that combines most of the performance and cost advantages of both the Rigid and Flex designs. The container is fabricated with two pieces cut from a tri-layered stock consisting of an inner sealant layer such as that used for flexible packaging, a rigid aluminum alloy sheet about $0.2-0.3 \mathrm{~mm}$ thick, and an outer layer that is electrically insulating. The pieces are shaped by stamping so that they enclose the cell and permit flat terminals to protrude between the container halves as for Flex cells. This stamping also makes ridges in one of the container pieces so that coolant passages are provided when the finished cells are strapped together into a module.

The container shells are fastened together by a simple mechanical closure at the sides and possibly the bottom of the cell. (The bottom would not require a seam if the container were made of one stamping instead of two and folded at the bottom.) These edge closures consist of a folded seam that is closed by stamping the entire closure after fitting the pieces together. After completing the mechanical closing of the container, the container can be sealed by heating the entire perimeter or by ultrasonic vibration to fuse the inner polymer layers. The seam will extend at the sides and bottom of the container by about 4 or $5 \mathrm{~mm}$ and provide a folded sealant width of 10 to $12 \mathrm{~mm}$ in these regions, about the same sealant width as that across the top of the cell, which includes the terminal seals. The width of these seals is important in slowing the rate of both water entry and electrolyte solvent loss. The aluminum layer is sufficiently thick to provide impermeability through the sidewalls.

\section{REFERENCES}

1. A. N. Jansen, K. Amine, and G. L. Henriksen, "Low-Cost Flexible Packaging for HighPower Li-Ion HEV Batteries,” Argonne National Laboratory Report ANL-04/09 (2004).

2. K. Richardson, B. Stein, P. Shah, N. Isaacs, and M. Milden, "Process Development of Electrode-Tab Welds for Aerospace, Lithium-Ion Cells,” Proc. Inter-Agency Energy Conversion Engineering Conference, July 26, 2000, AIAA-2000-2917 (2000).

3. Plastics Design Library, "Permeability and Other Film Properties of Plastics and Elastomers,” Plastics Design Library, New York, NY (1995). 


\section{APPENDIX A. DESIGN MODELING}

The performances were calculated for 25-kW Flex cell and Rigid cell batteries by means of a Microsoft Excel spreadsheet with a technique previously developed in this program [1-4]. In this technique the performance of the cell winding is calculated from data determined in the laboratory on small test cells. The program calculates the dimensions and weight of each cell and battery component, the resistances of each element in the current collection system, and thermal management parameters. All parameters are calculated simultaneously so that a change in one input parameter will cause the recalculation of all parameters affected by that input parameter. The performances of five batteries are usually calculated on a single spreadsheet so that the effects of changing a single variable can be easily assessed and graphed.

In designing the batteries, certain parameters were held constant for all designs to assure that all batteries in the study would have equal performance and meet the FreedomCar standards for hybrid vehicle batteries. Selected input parameters are shown in Table A.1. The value in the table for the area-specific impedance (ASI) of the electrodes and separator was determined by experiments on small cells with an area of $15.5 \mathrm{~cm}^{2}$.

Table A.1 Selected Input Parameters for Design Study

\begin{tabular}{|l|c|}
\hline \multicolumn{1}{|c|}{ Parameters } & Input Value \\
\hline Power for 10 seconds & \\
\hline Rated (End of Life) & $25 \mathrm{~kW}$ \\
\hline New Battery (30\% excess) & $32.5 \mathrm{~kW}$ \\
\hline Rated Regeneration Power (end of life) & $20 \mathrm{~kW}$ \\
\hline ASI of Electrodes and Separator for 10-s Power Burst & $25 \mathrm{ohm}-\mathrm{cm}^{2}$ \\
\hline Number of Cells, series connected & 20 \\
\hline Open Circuit Voltage at Full Power & $78 \mathrm{~V}$ \\
\hline Voltage for Maximum Discharge Pulse & $75 \%$ of OCV \\
\hline Cell Capacity & $20 \mathrm{Ah}$ \\
\hline
\end{tabular}

The values set for the battery power and for the voltage at full power determined the resistance of a new battery to be 0.0351 ohms. The number of wraps in the cell winding was examined as a variable. Design calculations were made for 18, 20, 23, 26 and 28 wraps around the flat winding core for both types of cells. The program calculated the resistance of the metallic conductors in the system and adjusted the area of the cells by changing the width of the cell in an iterative process (while holding the number of wraps and the height of the cell constant) until the battery resistance became $0.0351 \mathrm{ohms}$, matching that required of the set values for battery power and voltage. At the same time, the program automatically adjusted the cell loading density $\left(\mathrm{Ah} / \mathrm{cm}^{2}\right)$ to match the input value of cell capacity, resulting in battery energy storage of about $1.6 \mathrm{kWh}$ (evaluated at $\mathrm{C} / 1$ rate) for all cases.

Changing the number of cell wraps while maintaining the cell capacity at 20-Ah and the same winding height changes the width and thickness of the cell windings, as illustrated in Figure A.1 for Flex cells. The results are nearly identical for Rigid cells. Baseline designs with 
23 wrappings around the core were selected for both types of cells after studying these results and the thermal management requirements discussed in Appendix B. The decision for 23 wraps was based primarily on the need to have a thin cell for efficient cooling for both types of cells and the minimum cell thickness required for making connections to the terminals. Selected parameters for the baseline cells are shown in Table A.2.

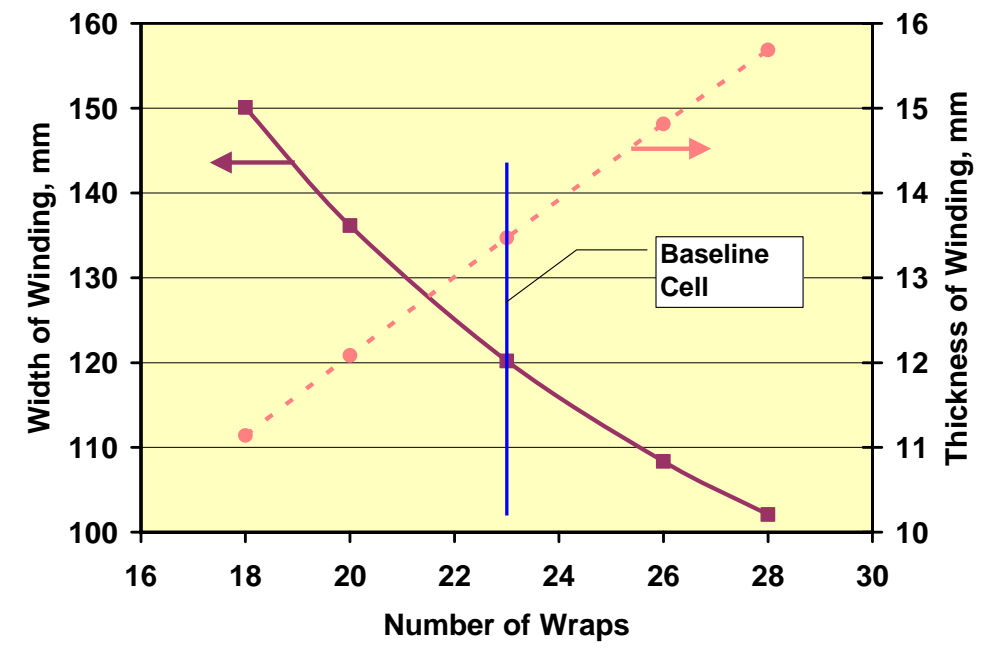

Fig. A.1. Effect of Number of Wraps on the Width and Thickness of 20-Ah Flex Cells

One factor in calculating the battery resistance is the resistance within the current collector foils. To determine this resistance, the impedance of a section of the cell winding that included one connection to the positive current collector foil and one to the negative current collector foil was calculated in a two-dimensional finite-element analysis (Flex PDE.4.0.6a by PDE Solutions, Inc.) for 59 cases covering a wide range of electrode dimensions. An areaspecific impedance (ASI) was ascribed to the current collection system itself by subtracting the area-specific impedance of the electrodes and separators from that of the entire winding section. It was found that the value used for the area specific impedance of the electrodes and separator in the calculation had very little effect $(<1 \%)$ on the net value calculated for the current collector system by this subtraction method. Also, whether both the negative and positive connections were on the top or one on the top and the other on the bottom had little effect. These results validated the approach of separating the measured value of the area-specific impedance of the electrodes and separator from the calculated area-specific resistance of the current collector foils. The resulting ASI for the current collectors was thus obtained for the 59 cases and empirically correlated (Fig. A.2). For that study the ranges of variables, as defined below, were A, 200 to $1600 \mathrm{~cm}^{2} ; \mathrm{H} / \mathrm{W}, 0.5$ to 1.4 ; and $\mathrm{T} / \mathrm{W}, 0.03$ to 0.47 . 
Table A.2. Comparison of Parameters for Baseline Flexible Packaging and Rigid Cells for 25-kW Hybrid Vehicle Batteries

\begin{tabular}{|c|c|c|c|}
\hline Cell Parameters & $\begin{array}{c}\text { Input } \\
\text { Values }\end{array}$ & Flex & Rigid \\
\hline Cell Capacity, C/1 rate, Ah & $*$ & 20 & 20 \\
\hline Positive Electrode First Charge Loading Density, mAh/ $\mathrm{cm}^{2}$ & & 1.37 & 1.35 \\
\hline Negative-to-Positive 1st Charge Capacity Ratio & $*$ & 1.2 & 1.2 \\
\hline $\begin{array}{l}\text { Coefficient of Capacity Delivered, mAh/g } \\
\text { Positive } \\
\text { Negative }\end{array}$ & $*$ & $\begin{array}{l}178 \\
338\end{array}$ & $\begin{array}{l}178 \\
338\end{array}$ \\
\hline $\begin{array}{l}\text { Positive Electrode Composition } \\
\text { Active material }\left(\mathrm{LiNi}_{1 / 3} \mathrm{Co}_{1 / 3} \mathrm{Mn}_{1 / 3} \mathrm{O}_{2} \text { ), wt } \%\right. \\
\text { Carbon (total), wt } \% \\
\text { Binder (PVDF), wt } \% \\
\text { Electrolyte fraction, vol\% }\end{array}$ & * & $\begin{array}{c}82 \\
10 \\
8 \\
32\end{array}$ & $\begin{array}{c}82 \\
10 \\
8 \\
32\end{array}$ \\
\hline $\begin{array}{l}\text { Positive Electrode Dimensions } \\
\text { Thickness of coating (applied on both sides), } \mu \mathrm{m} \\
\text { Width of coating, mm } \\
\text { Thickness of positive current collector, } \mu \mathrm{m}\end{array}$ & $\begin{array}{l}* \\
* \\
\end{array}$ & $\begin{array}{c}33 \\
150 \\
30\end{array}$ & $\begin{array}{c}33 \\
150 \\
30\end{array}$ \\
\hline $\begin{array}{l}\text { Negative Electrode Composition } \\
\text { Active material (graphite), wt } \% \\
\text { Binder (PVDF), wt } \% \\
\text { Electrolyte fraction, vol\% }\end{array}$ & * & $\begin{array}{c}92 \\
8 \\
34\end{array}$ & $\begin{array}{c}92 \\
8 \\
34\end{array}$ \\
\hline $\begin{array}{l}\text { Negative Electrode Dimensions } \\
\text { Thickness of coating (applied on both sides), } \mu \mathrm{m} \\
\text { Width of coating, mm } \\
\text { Thickness of negative current collector, } \mu \mathrm{m} \\
\end{array}$ & * & $\begin{array}{c}33 \\
153 \\
18\end{array}$ & $\begin{array}{c}33 \\
153 \\
18\end{array}$ \\
\hline $\begin{array}{l}\text { Cell Winding Parameters } \\
\text { Number of wraps } \\
\text { Height, mm } \\
\text { Width, mm } \\
\text { Thickness, mm } \\
\text { Thickness of core, mm } \\
\text { Total cell area, } \mathrm{cm}^{2}\end{array}$ & $*$ & $\begin{array}{c}23 \\
162 \\
120 \\
13.5 \\
2.0 \\
16,379\end{array}$ & $\begin{array}{c}23 \\
162 \\
122 \\
13.4 \\
2.0 \\
16,603\end{array}$ \\
\hline $\begin{array}{l}\text { Terminal Dimensions, mm } \\
\text { Flex cell terminal width } \\
\text { Flex cell terminal thickness } \\
\text { Rigid cell terminal threaded diameter } \\
\end{array}$ & * & $\begin{array}{l}38 \\
1.0\end{array}$ & 4.9 \\
\hline $\begin{array}{l}\text { Cell Dimensions, mm } \\
\text { Height } \\
\text { Width } \\
\text { Thickness } \\
\end{array}$ & & $\begin{array}{l}187 \\
144 \\
13.7\end{array}$ & $\begin{array}{l}169 \\
123 \\
14.3\end{array}$ \\
\hline Cell Weight, g & & 651 & 724 \\
\hline $\begin{array}{l}\text { Power Performance } \\
\text { ASI for 10-s power pulse, ohm-cm² } \\
\text { Cell rated power (end of life, } 10-\mathrm{s} \text { pulse) at } 25 \% \text { SOC, W } \\
\text { Cell specific power for new cell, kW/kg } \\
\end{array}$ & & $\begin{array}{c}28.5 \\
1,254 \\
2.50 \\
\end{array}$ & $\begin{array}{c}28.7 \\
1,256 \\
2.25\end{array}$ \\
\hline Cell Specific Energy (C/1 rate), Wh/kg & & 124 & 111 \\
\hline
\end{tabular}




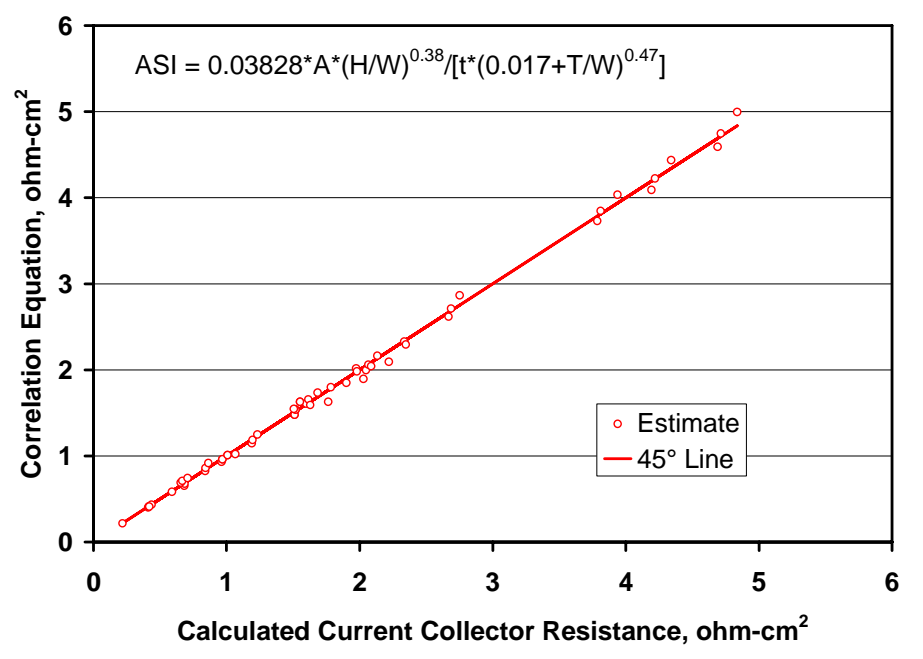

Fig. A.2. Correlation of Results Calculated by the Partial Differential Equation System (Flex PDE.4.0.6a by PDE Solutions, Inc.)

The following equation was found to fit the calculated values for the current collection system with an average error of $2.3 \%$ :

$$
\text { ASI }=0.03828 * \mathrm{~A} *(\mathrm{H} / \mathrm{W})^{0.38} /\left[\mathrm{t} *(0.017+\mathrm{T} / \mathrm{W})^{0.47}\right]
$$

where

ASI $=$ area specific impedance of the current collector system, ohm- $\mathrm{cm}^{2}$,

$\mathrm{A}=$ area of cell served by a single set of connections to terminal pieces, $\mathrm{cm}^{2}$,

$\mathrm{H}$ = electrode height, $\mathrm{cm}$,

$\mathrm{W}=$ width of area served, $\mathrm{cm}$,

$\mathrm{T}$ = width of tab or terminal piece making connection to the current collector foil, $\mathrm{cm}$, and

$\mathrm{t} \quad=$ thickness of aluminum positive current collector foil with copper negative foil thickness of 18/30th that of the positive foil, $\mu \mathrm{m}$.

To adapt this equation to a flat wound cell, the value of " $A$ " is calculated by dividing the total area of the positive electrode by the number of windings (or twice the number of windings if there are two connections to each terminal piece for every winding). Similarly, the "H/W" ratio is calculated as the height of the positive electrode divided by the quotient of the total coated length of the positive electrode and the total number of connections to the positive terminal piece.

The correlation equation can be solved in the Microsoft Excel spreadsheet in less than one millisecond, whereas the PDE method requires several seconds. More than 1000 solutions of the equation are required to solve the spreadsheet for a set of five battery designs because the current collector dimensions change with each spreadsheet iteration (total time to solution: about $10 \mathrm{~s})$. 
A breakdown of the battery resistance for 20-Ah baseline Flex Cells and Rigid cells is shown in Figure A.3. The major resistance for both batteries is in the electrodes and separator. The resistances of the terminals and the inter-cell connections are slightly higher for the Rigid cells. The diameter of the threaded terminals is slightly less than desired because of the narrowness of the cell and the need to provide nuts in the space available. Inter-cell connections have higher resistance for the Rigid cells because of the need for an additional connector piece between the cells that requires two connections, whereas the terminals of adjacent Flex cells are connected directly with a spring clip or by ultrasonic welding. The effects of the slightly higher resistances of these items for the Rigid cells is that the area of the cells must be $1.4 \%$ larger than that for the Flex cells so that the total battery resistances will be the same, resulting in the same power for both battery types.

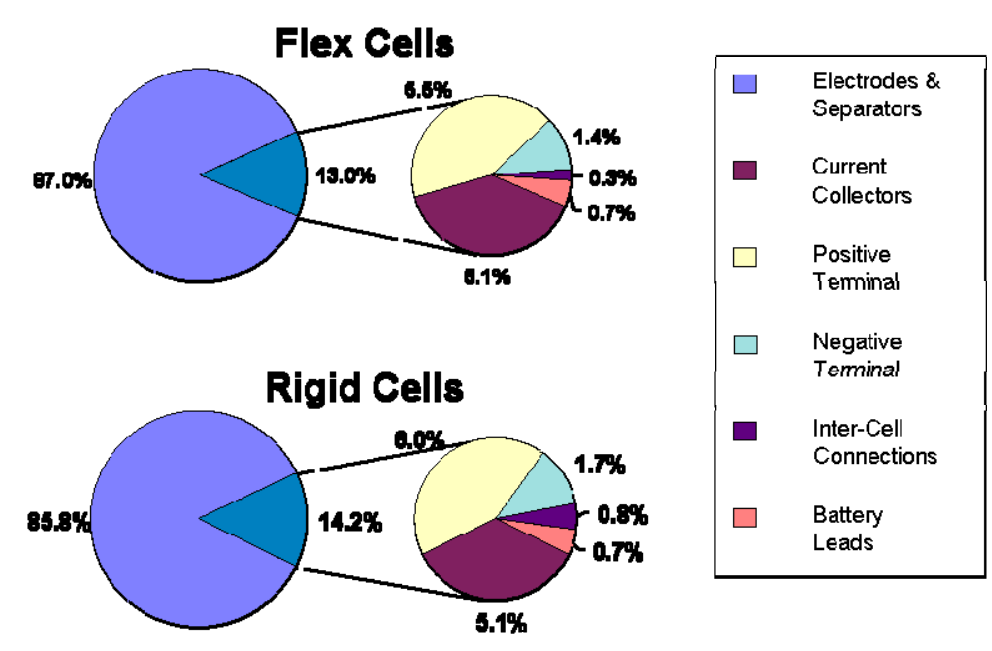

Fig. A.3. Breakdown of Battery Resistance for Baseline Flex Cells and Rigid Cells

As noted above, changing the number of wrappings in the winding changes the dimensions of the cell windings. The Flex cells are wider and taller than the Rigid cells (Table A.2) because of the sealing region in the Flex cells. It is necessary to incorporate the sealing region into the coolant distribution channels to achieve a compact design. This is discussed in Appendix B, Thermal Management. In the battery designs for both the Flex cell and the Rigid cells, the modules are enclosed in an insulated jacket that is hermetically sealed and cooled by a dielectric liquid. Sponge polymer seals between the module and the jacket (Section 2.7, Cost of Intercell Connections, Fig. 11) assist in directing the flow of coolant between the cells from one side of the jacket to the other. For the Flex cells, additional sponge polymer seals are shaped to fit the top and bottom of the cells (Fig. A.4). The jacket is sketched in Figure A.5, which also includes a table of overall dimensions for the two baseline battery systems.

The changes in cell dimensions caused by changing the number of cell wraps in the winding also affects the weight and volume of the batteries, as illustrated in Figure A.6. Over the ranges studied, these changes were not considered to be important in selecting the baseline cell designs. A breakdown of the weight of the battery parts for the Flex cell and Rigid cell batteries is shown in Figure A.7. 


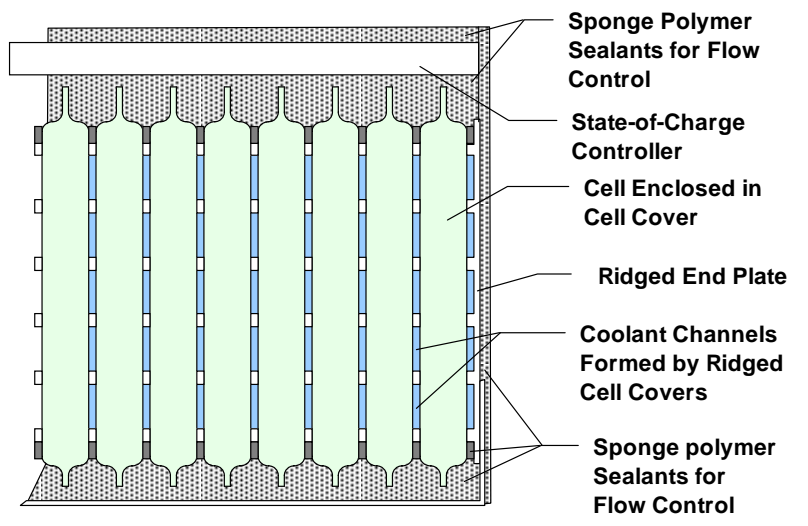

Fig. A.4. Cross-Section of Flex Cell Module Showing Flow Coolant Flow Passages

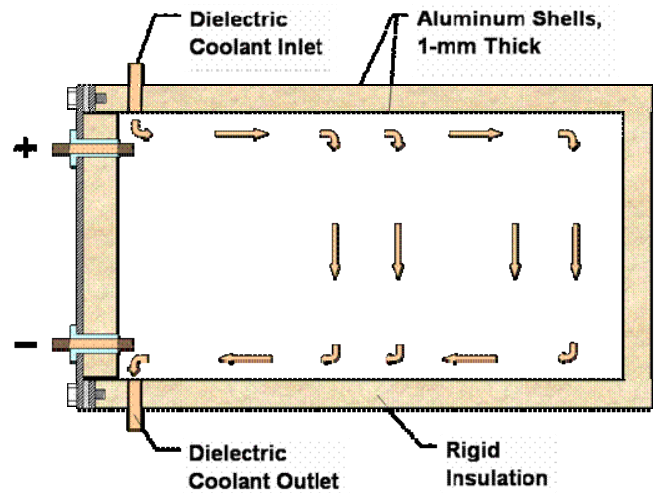

\begin{tabular}{lrr} 
& Flex & Rigld \\
\hline Length, mm & 348 & 341 \\
Woth, mm & 172 & 161 \\
Holght, mm & 234 & 212 \\
Volumm, L & 14 & 11 \\
Woloht kg & 20 & 10
\end{tabular}

Fig. A5. Insulated Battery Jacket Providing Cooling with Transformer Fluid

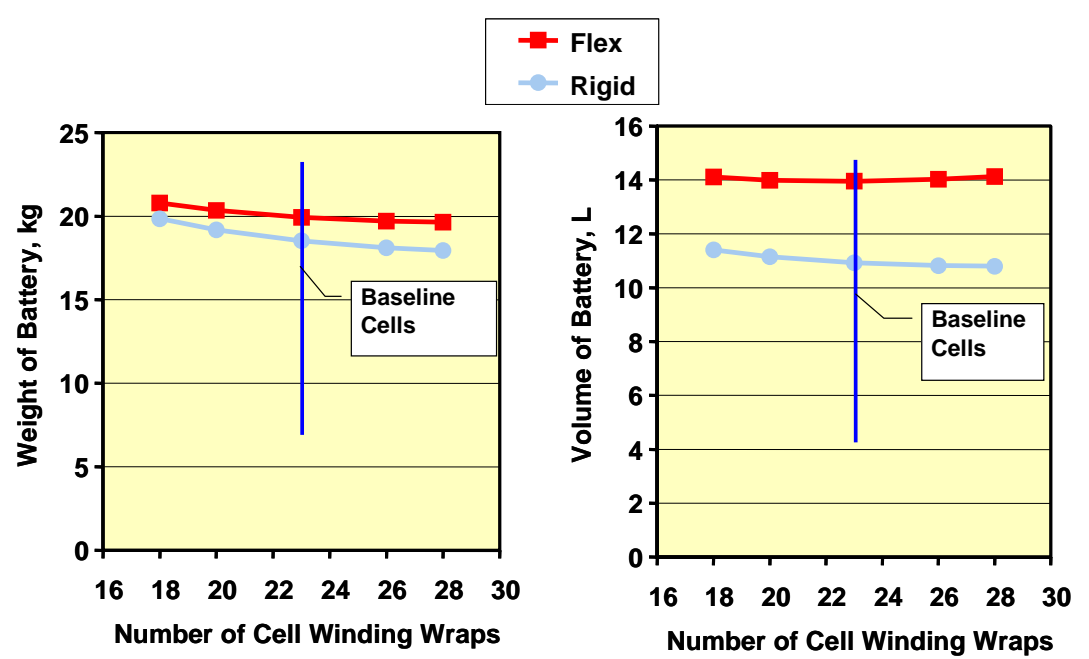

Fig. A.6. Weight and Volume of 25-kW Batteries of Flex Cells or Rigid Cells 


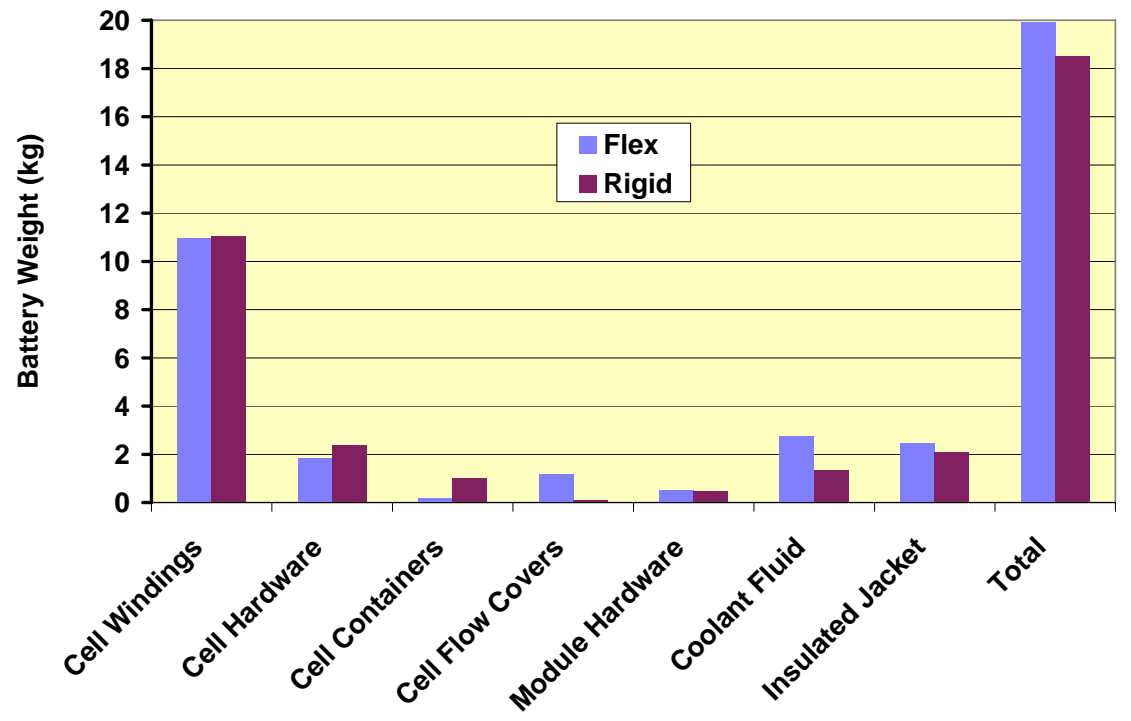

Fig. A.7. Weight Breakdown for 25-kW HEV Batteries of Baseline Design

\section{REFERENCES}

1. P. Nelson, D. Dees, K. Amine, and G. Henriksen, Journal of Power Sources 110(2), 349 (2002).

2. P. Nelson, I. Bloom, K. Amine, and G. Henriksen, Journal of Power Sources 110(2), 437 (2002).

3. P. Nelson, J. Liu, K. Amine, and G. Henriksen, ECS Proc. Vol. (F1) Power Sources Modeling (2003).

4. PNGV Battery Test Manual, Revision 3, DOE/ID-10597 (2001). 


\section{APPENDIX B. THERMAL MANAGEMENT}

Lithium-ion batteries for hybrid vehicles must have effective thermal management systems to avoid high temperatures, which may cause shorter cell life and lead to thermal runaway. It is apparent that the lower the temperature is maintained during operation and standby, the lower will be the rate of those deleterious effects to the battery that are inhibited only by chemical kinetics rather than the condition of thermodynamic stability. During cell malfunctions, high cell temperatures may lead to thermal runaway, which in many cases could be avoided by an efficient cooling system.

Maintaining the temperature as low as $10^{\circ} \mathrm{C}$, at which the power is only slightly reduced from that at room temperature, would be beneficial for the battery life. Fortunately, the lithiumion system is very powerful and the batteries in this study were designed to have excess power through most of their lives so that they can still achieve full power near end of life [1]. The design program that we use at Argonne National Laboratory designs the battery with $30 \%$ excess power (Appendix A, Table A.2) based on laboratory tests of the electrodes at $25^{\circ} \mathrm{C}$. It is estimated that at $10^{\circ} \mathrm{C}$ a new battery could achieve about $120 \%$ of the full design power. A strategy for achieving long life, therefore, is to control the normal operating temperature at only $10^{\circ} \mathrm{C}$ and to raise the control temperature near the end of battery life to maintain the full design power. This strategy requires the use of refrigeration. For the batteries in this study, a dedicated refrigeration system would only need to produce about $160 \mathrm{~W}$ of cooling, less than $2 \%$ of the maximum load on the air conditioning system for cooling the vehicle interior. This amount of cooling for the battery can be achieved by a compression system about the size of that in a student refrigerator or, at lower efficiency, by a thermal-electric system.

Another matter for concern is the response of the thermal control system to extreme ambient temperatures. The use of thermal insulation and control will help to avoid reaching high temperatures during parking on a sunny summer day (when the temperature in some parts of the vehicle may reach $60^{\circ} \mathrm{C}$ ) if the battery temperature prior to parking is only $10^{\circ} \mathrm{C}$ (Fig. B.1). After exposure to very cold ambient temperatures (down to $-30^{\circ} \mathrm{C}$ ) the battery would have sufficient power to start the vehicle and it could be heated sufficiently to achieve full power in about 5 to 10 minutes by heaters in the coolant circuit.

Both air and a dielectric liquid, such as Dow Corning 651 Transformer Fluid, were considered as coolants for this study. The initial cost is lower for air cooling than for dielectric cooling. With air cooling the requirement for a dedicated refrigeration system might be avoided by use of the air conditioning (AC) system in the vehicle to cool the battery with air diverted from that directed to cool the vehicle interior or by diverting refrigerant fluid from the compressor outlet to a separate evaporator to cool the battery coolant. 


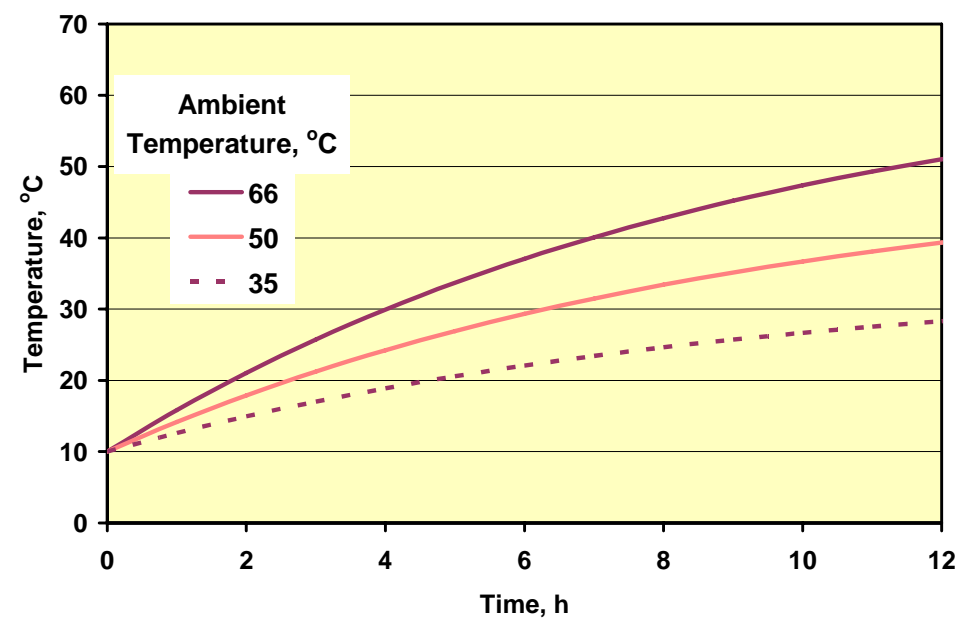

Fig. B.1. Heating of Battery during Standby for Various Ambient Temperatures

The efficient cooling of the battery during operation under normal conditions and cell failure conditions requires the use of forced cooling with thin coolant flow passages provided adjacent to the cells. Because the Flex cells and the Rigid cells are so similar in their dimensions and compositions, there is virtually no difference in their thermal performance. The Rigid cells are designed with a 40- $\mu \mathrm{m}$ polyimide layer between the electrodes and the electrically conductive container, which is not necessary for the Flex cells. However, the Flex cell container is less thermally conductive than the Rigid container. Both of these factors were taken into account, but the heat transfer across the cell layers per unit of temperature difference was calculated to be virtually the same for both types of baseline cells $\left(4.7 \mathrm{~W} /{ }^{\circ} \mathrm{C}\right.$ for the Rigid cell and $4.6 \mathrm{~W} /{ }^{\circ} \mathrm{C}$ for the Flex cell).

Some of the input parameters and the results of the thermal analysis are shown for the baseline Flex cells in Table B.1. The target heat rejection rate of $161 \mathrm{~W}$, which is equivalent to a $90 \%$ efficiency discharge at the C/1 rate, is a conservatively high rate of heat generation for a rigorous driving profile. The pressure drop for circulation of the coolant through the battery (Table B.1) is satisfactorily low so that the sealed battery jacket (Appendix A, Fig. A.5) can easily withstand the pressure. The power required for the fan to deliver air coolant to the battery would be much higher than that required for the pump to circulate the dielectric fluid even though the design temperature rise for the air coolant is four times as high as for the dielectric fluid. The temperature rise through the air film on the surface of the cell is much higher than through the dielectric fluid film. This is further illustrated in Figure B.2, in which the temperature rise is plotted as a function of the number of wraps in the cell winding (the baseline cell has 23 wraps) for both air cooling and dielectric fluid cooling for the target rate rejection rate of $161 \mathrm{~W}$ discussed above. 

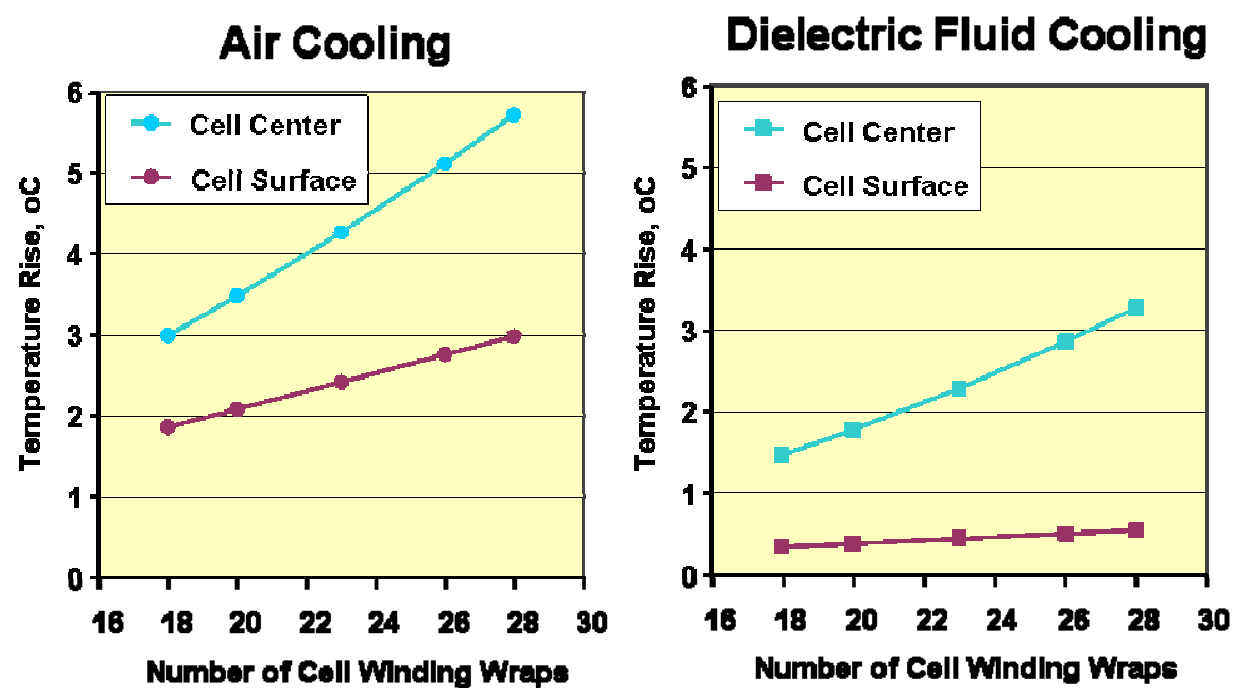

Fig. B.2. Temperature Rise above that of Adjacent Coolant for Flex Cells

Table B.1. Thermal Management Parameters for 25-kW Hybrid Vehicle Batteries with Flexible Package Cells

\begin{tabular}{|c|c|c|}
\hline & $\begin{array}{c}\text { Dielectric } \\
\text { Fluid } \\
\end{array}$ & Air \\
\hline Cell Dimensions, mm & \\
\hline Height & \multicolumn{2}{|c|}{187} \\
\hline Width & \multicolumn{2}{|c|}{144} \\
\hline Thickness & \multicolumn{2}{|c|}{14} \\
\hline Number of Cells & \multicolumn{2}{|c|}{20} \\
\hline Coolant Channel Thickness, mm & \multicolumn{2}{|c|}{1.0} \\
\hline Target Heat Rejection Rate for the Battery, W & \multicolumn{2}{|c|}{161} \\
\hline Coolant Temperature Rise Across Each Cell, ${ }^{\circ} \mathrm{C}$ & 1.0 & 4.0 \\
\hline Coolant Flow Rate per Cell, g/min & 321 & 122 \\
\hline $\begin{array}{l}\text { Pressure Drop in Coolant System, bar } \\
\text { Through passages between cells } \\
\text { Balance of system }\end{array}$ & $\begin{array}{l}0.019 \\
0.100 \\
\end{array}$ & $\begin{array}{c}0.0023 \\
0.003 \\
\end{array}$ \\
\hline Power to Motor for Pump or Fan, W & 1.9 & 30.3 \\
\hline $\begin{array}{l}\text { Temperature Rise above Coolant Temperature, }{ }^{\circ} \mathrm{C} \\
\text { To surface of cell } \\
\text { To center of cell }\end{array}$ & $\begin{array}{l}0.4 \\
2.3\end{array}$ & $\begin{array}{l}2.4 \\
4.3\end{array}$ \\
\hline
\end{tabular}

The advantages of cooling with a dielectric fluid are especially apparent for cooling a malfunctioning cell. If a cell develops an internal short circuit or begins to generate heat at a high rate for some other reason, both a low temperature difference between the cell centerline and the coolant and a low temperature rise for the coolant in passing over the cell become important safety factors that will permit a large increase in the heat rejection rate from the cell. 
Since no more than one cell is likely to malfunction at any one time and the coolant from the malfunctioning cell is mixed with that from the other cells, the cooling system can handle a heat generation rate in the malfunctioning cell that is many times larger than the design rate. As the heating rate in the malfunctioning cell rises well above the design cooling rate, the difference between the temperature at the center plane of the cell and that of the coolant increases and the temperature of the coolant as it leaves the cell increases. The maximum temperature at steady state occurs at the center plane of the cell near the end of the coolant passage. The dielectric coolant is more effective than air because of its higher thermal conductivity, which results in lower cell surface temperatures (Fig. B.3), and its higher heat capacity, which results in a lower temperature rise for the coolant. If the total electrochemical energy in the cell is converted to heat at a constant rate, then the maximum steady-state temperature in the cell will be much higher for air cooling than for dielectric fluid cooling and these temperatures will depend on the energy conversion rate (Fig. B.4).

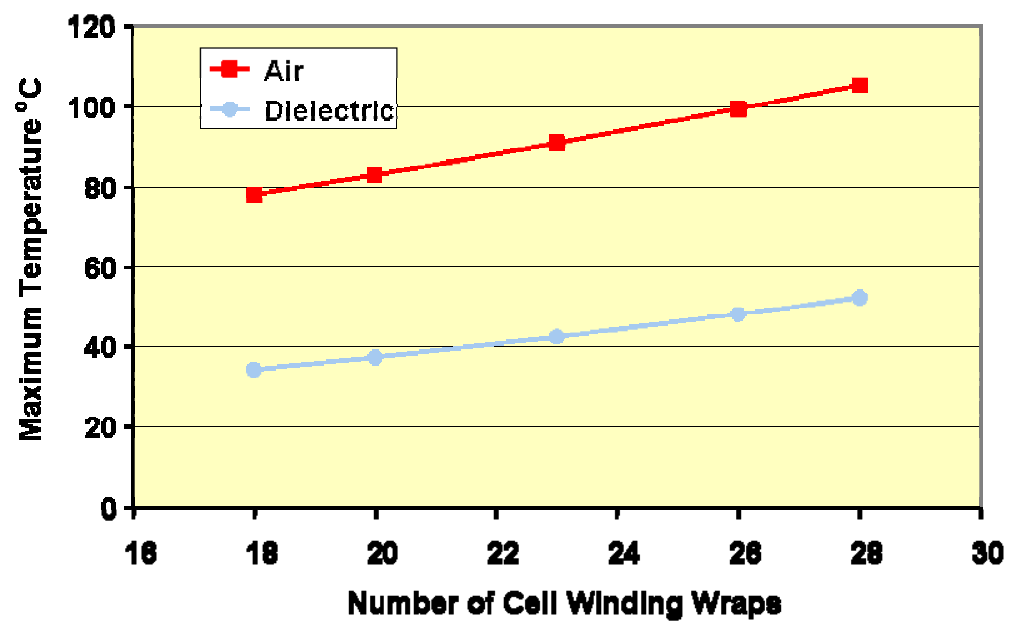

Fig. B.3. Maximum Temperature Reached at Center of Flex Cell during Malfunction that Converts Total Electrochemical Energy of Fully Charged Cell to Heat at C/1 Rate with Coolants at $10^{\circ} \mathrm{C}$ Inlet Temperature 


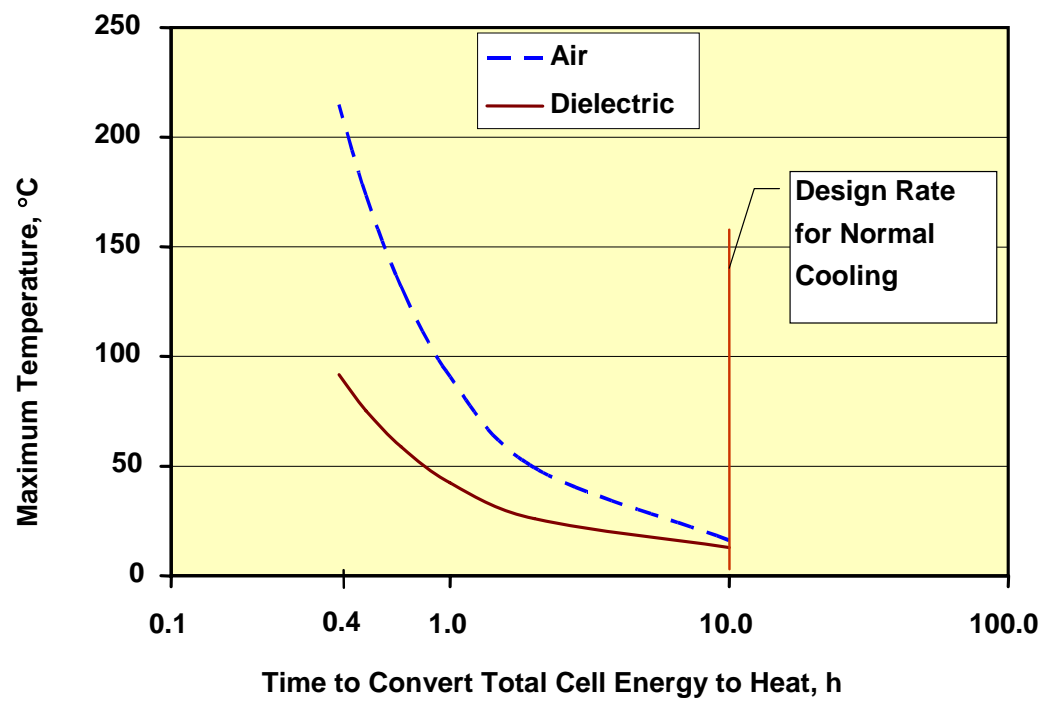

Fig. B.4. Maximum Temperature Reached at Center of Base Line Flex Cell (23 wraps) as Function of Heat Generation Expressed as the Time to Convert the Total Electrochemical Cell Energy to Heat with Coolants at $10^{\circ} \mathrm{C}$ Inlet Temperature

Factors in favor of dielectric coolant rather than air include (1) more effective cooling, especially during cell malfunctioning with high rates of heat release; (2) a cleaner coolant system unaffected by dust, moisture, ozone, and salt spray in the ambient air; (3) lower power for circulating the coolant, which has a value over the life of the battery that is at least as high as the initial cost of the dielectric coolant; and (4) non-combustion in the event of a cell breach and exposure of the cell interior to the coolant.

\section{REFERENCES}

1. PNGV Battery Test Manual, Revision 3, DOE/ID-10597 (2001). 


\section{APPENDIX C. SAFETY AND MONITORING}

Gases are generated within lithium-ion cells during normal operations such as formation cycling and charging and during abuse conditions such as overcharging and overdischarging. The cells must be designed to withstand the pressure for normal and mild abuse conditions, but relieve high pressures of two or three atmospheres. Relief of pressure has been accomplished by the use of rupture discs for both prismatic and cylindrical cells [1]. Flex cells can also be designed to release at the desired pressure [2]. The testing of Flex cells for gas release under abuse conditions must be done with the aluminum cell covers in place since these covers are clamped together by the endplates and straps in the module, which may interfere with the release of pressure for some designs (Section 2.7, Cost of Intercell Connections, Fig.11).

Another safety device has been developed for both cylindrical and prismatic lithium-ion cells that breaks the aluminum lead from the positive electrode to the positive terminal when actuated by high internal cell pressure [1]. The breaking of the lead stops the abuse before the temperature and pressure become so excessive that the cell ruptures. A similar device has been proposed for cells for hybrid-electric vehicle (HEV) batteries, but for a battery of many cells in series the use of such a devise is inadvisable. The ends of the broken lead would have the full battery voltage impressed on them in the presence of electrolyte and possibly oxygen from the positive electrode, which might result in an explosion due to arcing across the broken lead.

It may be possible to incorporate safety devices into Flex cells of the same type as have been proposed for the rigid cells. The flexible packaging itself would not interfere with such a mechanism. For the same cell chemistry and cell capacity, the cross-section over which the actuating force would be generated for breaking of an internal cell lead would be the same. However, the design of the mechanism might be easier for cylindrical cells than for prismatic cells.

A more promising approach for dealing with high cell pressures is the use of a pressuresensitive switch located, for instance, between the flexible package and the rigid aluminum cover (Section 2.5, Cost of Provision for Cooling Channels, Fig. 9). A high pressure in the cell would actuate the switch and cause the main battery breaker to open. Because of the flexibility of the cell container, the pressure between the cover and the Flex cell is essentially the same as that within the cell. If the abuse condition is detected and corrected after the pressure switch has actuated, the abused cell will still be functional, whereas actuation of a device within the cell, for instance to break the lead to the positive current collector, is not reversible and will result in the loss of the cell and the loss of the entire module, since replacement of a cell within a module is impractical.

This approach may also be applicable to some Rigid cell designs having somewhat flexible sides, permitting actuation of a pressure switch outside of the cell. The location of the switch for best results could be determined in a test program. An external pressure switch could not be easily applied for a cylindrical cell, which is too rigid.

The proposed pressure-activated device for actuating the main battery circuit breaker for both the Flex cell and the Rigid cell would be in addition to other safety measures. These 
measures should include: (1) automatic state-of-charge equalization of cells during periods of battery inactivity longer than 15 minutes; (2) redundant monitoring and control of the battery voltage to avoid overcharging of the battery; (3) voltage monitoring of each cell with warning lights and opening of the main battery circuit breaker, if warranted; (4) temperature monitoring of each coolant passage between cells, which would give a separate distress signal for each side of the cell (providing redundancy), with action taken at high temperature; (5) high-efficiency cooling for high cell temperatures caused by cell abuse or cell malfunctioning, with the capability of removing heat at ten times the design rate for normal vigorous battery operation.

\section{REFERENCES}

1. D. Linden and T. B. Reddy, Handbook of Batteries, third edition, McGraw-Hill, New York, NY (2002).

2. N. Jansen, K. Amine, and G. L. Henriksen, "Low-Cost Flexible Packaging for High-Power Li-Ion HEV Batteries,” Argonne National Laboratory Report ANL-04/09 (2004). 


\section{APPENDIX D. COMPANY CONTACT INFORMATION}

Following is an alphabetical list of companies, with associated contact information:

\section{Company Information}

CROWN Packaging Technology, Inc.

11535 South Central Avenue

Alsip, IL 60803

Tel: $\quad$ 708-239-5273

Fax: 708-239-5453

E-mail: mike.gredlics@crowncork.com

Internet: www.crowncork.com

Flex-Pak Packaging Products, Inc.

651 N. Raddant Rd.

Batavia, IL 60510

Tel: $\quad 630-761-3335$

Fax: 630-761-3336

Internet: www.flex-pak.biz

Integrated Solutions

3242 Monroe Street

Waukegan, IL 60085

Tel: $\quad 847-623-3695$

Fax: 847-623-3726

E-mail: rhinoje@aol.com

Plastic Technology Partners

605 Leesburg Ct.

Naperville, IL 60540

Tel: $\quad$ 630-357-2894

E-mail: scornell.ptp@juno.com

Sumitomo Electric Flat Components, Inc.

(A subsidiary of Sumitomo Electric Industries, LTD.)

3-3, Satsuki-cho, Kanuma,

Tochigi, 322-8585 Japan

Tel: $\quad$ 0289-76-0334

Fax: 0289-76-3485

E-mail: hosokawa@sei.co.jp

Internet: www.sei.co.jp $\underline{\text { Contact }}$

Mike Gredlics

William Reimann

James Rinehart

Stephen W. Cornell

Takehiro Hosokawa 


\section{Distribution for ANL-05/59}

Internal (Printed Copy):

P. A. Nelson

A. N. Jansen

K. Amine

G. L. Henriksen (50)

D. W. Dees

M. M. Thackeray

I. D. Bloom

D. R. Vissers

D. P. Abraham

I. Belharouak

C. S. Johnson

S.-H. Kang

J. Liu

J. T. Vaughey

J. F. Miller

Internal (Electronic Copy):

D. Graziano

\section{External (Printed Copy Only):}

M. Alamgir, Compact Power, Monument, CO

M. Andrew, Johnson Controls Inc., Milwaukee, WI

C. Ashtiani, DaimlerChysler, Rochester Hills, MI

T. Atwater, U.S. Army RDECOM, Fort Monmouth, NJ

J. Barnes, USDOE, Washington, DC

V. Battaglia, Lawrence Berkeley National Laboratory, Berkeley, CA

R. Brodd, Broddarp of Nevada, Inc., Henderson, NV

S. Cornell, Plastic Technology Partners, Naperville, IL

J. Deppe, Davidsonville, MD

J. DiCarlo, Lithion, Inc., Pawcatuck, CT

D. Doughty, Sandia National Laboratories, Albuquerque, NM

T. Duong, USDOE, Washington, DC

K. Gering, INEEL, Idaho Falls, ID

M. Gredlics, CROWN Packaging Technology, Inc., Alsip, IL

M. A. Habib, General Motors Corp., Warren, MI

H. Haskins, Corvallis, OR

E. Heim, San Rafael, CA

M. Hoenigmann, Pliant Corp., Chippewa Falls, WI

T. Hosokawa, Sumitomo Electric Flat Components, Inc., Tochigi, Japan

D. Howell, USDOE, Washington, DC 
N. Isaacs, Mine Safety Appliances Company, Sparks, MD

L. Jenkins, CROWN Packaging Technology, Inc., Alsip, IL

T. R. Jow, Army Research Laboratory, Adelphi, MD

K. Kepler, Farasis Energy, Inc., Alameda, CA

G. MacLean, General Motors Corp., Warren, MI

V. Manev, Altair Nanotechnologies, Inc., Reno, NV

F. R. McLarnon, Lawrence Berkeley National Laboratory, Berkeley, CA

T. Miller, Ford Motor Co., Dearborn, MI

R. Minck, Laguna Niguel, CA

T. Murphy, INEEL, Idaho Falls, ID

K. Nechev, SAFT America, Inc., Cockeysville, MD

N. Pinsky, Southern California Edison, Rosemead, CA

N. Raman, SAFT America, Inc., Cockeysville, MD

W. Reimann, Flex-Pak Packaging Products, Inc., Batavia, IL

J. Rinehart, Integrated Solutions, Waukegan, IL

S. Saffe, Kapak Corp., Minneapolis, MN

L. Simmering, Ford Motor Co., Dearborn, MI

J. Stockel, NRO/CIA, Chantilly, VA

J. Swamy, Pliant Corp., Chippewa Falls, WI

J. Symanski, Johnson Controls Inc., Milwaukee, WI

H. Tataria, General Motors Corp., Troy, MI

T. Tran, Sentech, Inc., Bethesda, MD

M. Verbrugge, General Motors Corp., Troy, MI

A. Webber, Energizer, Westlake, $\mathrm{OH}$

X.-Q. Yang, Brookhaven National Laboratory, Upton, NY

External (Electronic Copy):

M. A. Buckley, ANL Library-E 
Argonne

Chemical Engineering Division

Argonne National Laboratory

9700 South Cass Avenue, Bldg. 205

Argonne, IL 60439-4837

www.anl.gov

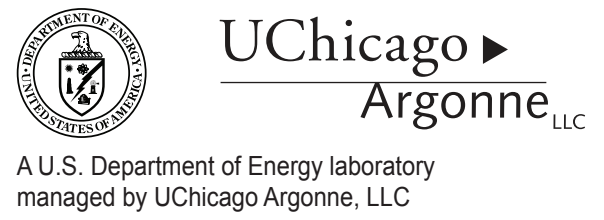

